\title{
The influence of foreign vs. North American emissions on surface ozone in the US
}

\author{
D. R. Reidmiller ${ }^{1,2}$, A. M. Fiore ${ }^{3}$, D. A. Jaffe ${ }^{2}$, D. Bergmann ${ }^{4}$, C. Cuvelier ${ }^{5}$, F. J. Dentener ${ }^{5}$, B. N.Duncan ${ }^{6, *}$, \\ G. Folberth ${ }^{7}$, M. Gauss ${ }^{8}$, S. Gong ${ }^{9}$, P. Hess ${ }^{10, * *}$, J. E. Jonson ${ }^{11}$, T. Keating ${ }^{12}$, A. Lupu ${ }^{13}$, E. Marmer ${ }^{5}$, R. Park ${ }^{14, * * *}$, \\ M. G. Schultz ${ }^{15}$, D. T. ShindelI ${ }^{16}$, S. Szopa ${ }^{17}$, M. G. Vivanco ${ }^{18}$, O. Wild ${ }^{19}$, and A. Zuber ${ }^{20}$ \\ ${ }^{1}$ University of Washington, Department of Atmospheric Sciences, Seattle, WA, USA \\ ${ }^{2}$ University of Washington - Bothell, Department of Interdisciplinary Arts and Sciences, Bothell, WA, USA \\ ${ }^{3}$ NOAA Geophysical Fluid Dynamics Laboratory, Princeton, NJ, USA \\ ${ }^{4}$ Atmospheric Earth and Energy Division, Lawrence Livermore National Laboratory, Livermore, CA, USA \\ ${ }^{5}$ European Commission, Joint Research Centre JRC, Institute for Environment and Sustainability, Ispra, Italy \\ ${ }^{6}$ Goddard Earth Sciences \& Technology Center, UMBC, MD, USA \\ ${ }^{7}$ Ecole Polytechnique Fédérale de Lausanne (EPFL), Lausanne, Switzerland \\ ${ }^{8}$ Department of Geosciences, University of Oslo, Oslo, Norway \\ ${ }^{9}$ Science and Technology Branch, Environment Canada, Toronto, ON, Canada \\ ${ }^{10}$ National Center for Atmospheric Research, Boulder, CO, USA \\ ${ }^{11}$ Norwegian Meteorological Institute, Oslo, Norway \\ ${ }^{12}$ Office of Policy Analysis and Review, EPA, Washington, DC, USA \\ ${ }^{13}$ Center for Research in Earth and Space Science, York University, Toronto, ON, Canada \\ ${ }^{14}$ Atmospheric Chemistry Modeling Group, Harvard University, Cambridge, MA, USA \\ ${ }^{15}$ ICG-2, Forschungszentrum Jülich, Jülich, Germany \\ ${ }^{16}$ NASA Goddard Institute for Space Studies and Columbia University, New York, NY, USA \\ ${ }^{17}$ Laboratoire des Sciences du Climat et de l'Environnement, CEA/CNRS/UVSQ/IPSL, Gif-sur-Yvette, France \\ ${ }^{18}$ Centro de Investigaciones Energéticas, Medioambientales y Tecnológicas (CIEMAT), Madrid, Spain \\ ${ }^{19}$ Lancaster Environment Centre, Lancaster University, Lancaster, UK \\ ${ }^{20}$ Environment Directorate General, European Commission, Brussels, Belgium \\ *now at: NASA Goddard Space Flight Center, Greenbelt, MD, USA \\ **also at: Cornell University, Ithaca, New York, USA \\ ${ }^{* * *}$ now at: Seoul National University, Seoul, Korea
}

Received: 23 February 2009 - Published in Atmos. Chem. Phys. Discuss.: 25 March 2009

Revised: 18 June 2009 - Accepted: 15 July 2009 - Published: 27 July 2009

\begin{abstract}
As part of the Hemispheric Transport of Air Pollution (HTAP; www.htap.org) project, we analyze results from 15 global and 1 hemispheric chemical transport models and compare these to Clean Air Status and Trends Network (CASTNet) observations in the United States (US) for 2001. Using the policy-relevant maximum daily 8-h average ozone $\left(\mathrm{MDA} 8 \mathrm{O}_{3}\right)$ statistic, the multi-model ensemble represents the observations well (mean $r^{2}=0.57$, ensemble bias $=+4.1 \mathrm{ppbv}$ for all US regions and all seasons) despite a wide range in the individual model results. Correlations
\end{abstract}

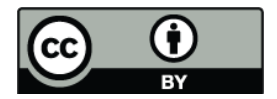

Correspondence to: D. R. Reidmiller (dreidm@atmos.washington.edu) are strongest in the northeastern US during spring and fall $\left(r^{2}=0.68\right)$; and weakest in the midwestern US in summer $\left(r^{2}=0.46\right)$. However, large positive mean biases exist during summer for all eastern US regions, ranging from 10$20 \mathrm{ppbv}$, and a smaller negative bias is present in the western US during spring ( $\sim 3 \mathrm{ppbv})$. In nearly all other regions and seasons, the biases of the model ensemble simulations are $\leq 5 \mathrm{ppbv}$. Sensitivity simulations in which anthropogenic $\mathrm{O}_{3^{-}}$ precursor emissions $\left(\mathrm{NO}_{\mathrm{x}}+\mathrm{NMVOC}+\mathrm{CO}+\right.$ aerosols) were decreased by $20 \%$ in four source regions: East Asia (EA), South Asia (SA), Europe (EU) and North America (NA) show that the greatest response of $\mathrm{MDA} 8 \mathrm{O}_{3}$ to the summed foreign emissions reductions occurs during spring in the

Published by Copernicus Publications on behalf of the European Geosciences Union. 
West $(0.9 \mathrm{ppbv}$ reduction due to $20 \%$ emissions reductions from $\mathrm{EA}+\mathrm{SA}+\mathrm{EU})$. East Asia is the largest contributor to MDA8 $\mathrm{O}_{3}$ at all ranges of the $\mathrm{O}_{3}$ distribution for most regions (typically $\sim 0.45 \mathrm{ppbv}$ ) followed closely by Europe. The exception is in the northeastern US where emissions reductions in EU had a slightly greater influence than EA emissions, particularly in the middle of the MDA8 $\mathrm{O}_{3}$ distribution (response of $\sim 0.35 \mathrm{ppbv}$ between $35-55 \mathrm{ppbv}$ ). EA and EU influences are both far greater (about $4 \times$ ) than that from SA in all regions and seasons. In all regions and seasons $\mathrm{O}_{3}$-precursor emissions reductions of $20 \%$ in the NA source region decrease MDA8 $\mathrm{O}_{3}$ the most - by a factor of 2 to nearly 10 relative to foreign emissions reductions. The $\mathrm{O}_{3}$ response to anthropogenic NA emissions is greatest in the eastern US during summer at the high end of the $\mathrm{O}_{3}$ distribution (5-6 ppbv for 20\% reductions). While the impact of foreign emissions on surface $\mathrm{O}_{3}$ in the US is not negligible and is of increasing concern given the recent growth in Asian emissions - domestic emissions reductions remain a far more effective means of decreasing MDA8 $\mathrm{O}_{3}$ values, particularly those above $75 \mathrm{ppb}$ (the current US standard).

\section{Introduction}

It is well-established that the intercontinental transport of pollutant emissions affects surface air quality in the United States (Berntsen et al., 1999; Jacob et al., 1999; Jaffe et al., 1999; Fiore et al., 2002; Goldstein et al., 2004; Keating et al., 2005; Sudo and Akimoto, 2007; Lin et al., 2008; Oltmans et al., 2008; Zhang et al., 2008; Fischer et al., 2009). Transport "events" can lead to exceedances in air quality standards for downwind regions (Jaffe et al., 2004). As a result, foreign emissions can significantly affect the health of humans and crops in the US (Bell et al., 2004; Ellingsen et al., 2008; Casper-Anenberg et al., 2009). However, the effect foreign emissions have on air quality in the US can vary significantly on time-scales from days (Yienger et al., 2000; Liang et al., 2007) to months (Liu et al., 2003; Liang et al., 2004; WeissPenzias et al., 2004; Wang et al., 2006) to years (Liang et al., 2005; Liu et al., 2005; Reidmiller et al., 2009).

Over the past 15 years, a multitude of field campaigns have attempted to quantify the effect of Asian emissions on US air quality and how these emissions are affecting the photochemical environment over the North Pacific. The Pacific Exploratory Mission - West phase (PEM-West; Hoell et al., 1997) took place in 1994 to study the chemical outflow from East Asian emissions. The Photochemical Ozone Budget of the Eastern North Pacific Atmosphere (PHOBEA; Jaffe et al., 2001; Kotchenruther et al., 2001; Bertschi et al., 2004) campaign was a multi-year investigation spanning 1997-2002 using aircraft and ground measurements to quantify the impacts of Asian emissions on pollutant inflow to the northwestern US. The Transport and Chemical Evolution over the
Pacific (TRACE-P; Jacob et al., 2003) and Intercontinental Transport and Chemical Transformation (ITCT 2K2; Parrish et al., 2004a; Goldstein et al., 2004) campaigns were conducted during spring - the season of greatest East Asian transport to North America - of 2001 and 2002, respectively. In 2004, the Pacific Exploration of Asian Continental Emission (PEACE; Parrish et al., 2004a) experiment was carried out in two phases over winter and spring to determine seasonal differences in transpacific transport and photochemical environments. Also in 2004, a remote free tropospheric site near the US west coast was established atop Mt. Bachelor in central Oregon $\left(43.98^{\circ} \mathrm{N}, 121.69^{\circ} \mathrm{W} ; 2.7 \mathrm{~km}\right.$ a.s.l.) allowing frequent observations of Asian pollution plumes in the US (Weiss-Penzias et al., 2006; Swartzendruber et al., 2006). Most recently, in spring 2006, the Intercontinental Chemical Transport Experiment (INTEX-B; Singh et al., 2009) was a coordinated satellite, aircraft and ground-based campaign designed in large part to quantify the import of Asian pollutants to western North America. Additionally, satellite data are now being used to better understand and quantify the intercontinental transport of pollutants (Heald et al., 2003; Damoah et al., 2004; Creilson et al., 2003; Wenig et al., 2003).

Similarly, North American emissions affect air quality in downwind regions, as well. The North Atlantic Regional Experiment (NARE) and the International Consortium for Atmospheric Research on Transport and Transformation (ICARTT) both quantified the outflow of North American emissions and their impacts on downwind regions (Parrish et al., 2004b; Li et al., 2004; Hudman et al., 2007). Along a similar vein, Cooper et al. (2005) used ozonesonde and MOZAIC aircraft data to quantify transport pathways on the inflow (west coast) and outflow (east coast) regions of the US. Li et al. (2002) found that North American anthropogenic emissions enhance surface $\mathrm{O}_{3}$ in continental Europe by $2-4$ ppbv on average during summer and by $5-10 \mathrm{ppbv}$ during trans-Atlantic transport events.

Beyond field campaigns and satellite observations, global chemical transport models (CTMs) are valuable tools with which we can quantify the intercontinental transport of pollution. While the existing literature on this topic is expansive (e.g., Klonecki and Levy, 1997; Jacob et al., 1999; Yienger et al., 1999, 2000; Fiore et al., 2002, 2003; Liang et al., 2004, 2005, 2007; Auvray et al., 2007; Lin et al., 2008), there is a lack of coherency in these individual modeling studies that makes it difficult to draw any meaningful conclusions about the magnitude of the foreign influence on surface $\mathrm{O}_{3}$ in the US. In response to this, the UN Economic Commission for Europe's Convention on Long-Range Transboundary Air Pollution developed the Task Force on Hemispheric Transport of Air Pollution (TF HTAP; http://www.htap.org) in December 2004. A major TF HTAP activity was to design a set of simulations that were executed by $20+$ modeling groups in an effort to quantify the source-receptor relationships for various pollutants including $\mathrm{O}_{3}, \mathrm{Hg}$, aerosols and 
persistent organic pollutants (TF HTAP, 2007). Its objectives are to understand the key processes governing intercontinental transport, quantify source-receptor relationships and identify future research needs. In addition to the HTAP interim report (TF HTAP, 2007), several studies have utilized this valuable data set: Sanderson et al. (2008) investigate how nitrogen deposition is affected by intercontinental transport; Shindell et al. (2008) determine source attribution for pollutants transported to the Arctic; Fiore et al. (2009) quantify the source-receptor relationships for ground-level $\mathrm{O}_{3}$ pollution using four northern hemispheric $(\mathrm{NH})$ regions - East Asia (EA), South Asia (SA), Europe (EU) and North America (NA); Casper-Anenberg et al. (2009) estimate the mortalities avoided by $20 \%$ reductions of anthropogenic $\mathrm{O}_{3}$ precursor emissions in the four source regions; Jonson et al. (2009) investigate the ability of the models to capture vertical $\mathrm{O}_{3}$ distributions as measured by ozonesondes and intercontinental contribution throughout the atmospheric column.

Our objectives are to: (1) assess the multi-model skill in reproducing the observed maximum daily 8 -h average $\mathrm{O}_{3}$ (MDA8 $\mathrm{O}_{3}$ ) statistic, (2) determine the contribution from intercontinental sources to surface $\mathrm{O}_{3}$ in the US, and (3) compare foreign vs. NA influences on MDA8 $\mathrm{O}_{3}$ and how this relationship varies by region, season and across the $\mathrm{O}_{3}$ distribution. The method adopted here begins by selecting regionally-representative CASTNet sites, putting observations from 2001 (the year of the HTAP simulations) in context with climatological $\mathrm{O}_{3}$ behavior (Sect. 2.1) and briefly describing the global models used (Sect. 2.2). We then assess the ability of the multi-model mean to reproduce observed MDA8 $\mathrm{O}_{3}$ in various regions on seasonal, monthly and daily timescales (Sect. 3). Finally, we use the perturbation simulations in which NA and foreign (i.e., $\mathrm{EA}+\mathrm{SA}+\mathrm{EU}$ ) anthropogenic $\mathrm{O}_{3}$-precursor emissions were reduced by $20 \%$ to quantify the differences between foreign (Sect. 4) vs. domestic sources (Sect. 5) on MDA8 $\mathrm{O}_{3}$ throughout the US in different seasons and across the $\mathrm{O}_{3}$ distribution.

\section{Methodology}

\subsection{CASTNet observations}

As required by the Clean Air Act Amendments of 1990, CASTNet was developed by the US Environmental Protection Agency (EPA) in order to establish an effective, rural monitoring and assessment network at locations away from pollutant emission sources and heavily populated areas (US EPA, 2008; Eder et al., 2005). Monitoring locations were selected according to strict siting criteria designed to avoid undue influence from point sources, area sources and local activities. As a result, most CASTNet sites are located in rural areas with open, rolling terrain, well-removed from emission sources (Holland et al., 1999; Tong and Mauzerall, 2006).
The primary purpose of CASTNet is to identify and characterize broad-scale spatial and temporal trends of various air pollutants and their environmental effects (Eder et al., 2005). The network was developed from the existing National Dry Deposition Network and has become the nation's primary monitoring network for measuring concentrations of rural ambient (background) $\mathrm{O}_{3}$ levels. A selection of studies using CASTNet $\mathrm{O}_{3}$ data include investigations of: subgrid segregation on ozone production efficiency in a chemical model (Liang and Jacobson, 2000); variability in surface background $\mathrm{O}_{3}$ throughout the US (Lefohn et al., 2001; Fiore et al., 2003); and the positive trend in $\mathrm{O}_{3}$ throughout the western US (Jaffe and Ray, 2007).

Figure 1 illustrates the 83 currently operational CASTNet sites. Table A1 lists the geographic information (latitude, longitude and elevation) for these CASTNet sites. We divide the US into nine broad geographic regions based on boundaries of the EPA's 10 Regions, CASTNet site density and basic geographical and topographical features. Since the HTAP project uses CTMs with typical resolutions of $100-500 \mathrm{~km}$, we attempt to use the CASTNet observations in a manner representative of these large spatial scales. As a result, we determine "regionally-representative" sites through a unique methodology, but with a similar goal and outcome to that of Lehman et al. (2004) and Fuentes (2003).

We calculate monthly mean MDA8 $\mathrm{O}_{3}$ for each of the 68 sites with nearly complete records in 2001 ( $\geq 21$ days of data per month; Figs. 2 and A1). (Note, from here onward we compare the Mountain West and Southeast regions in this article to show differences in East vs. West US regions; results from the other seven regions are in the Auxiliary Materials: http://www.atmos-chem-phys.net/9/5027/ 2009/acp-9-5027-2009-supplement.pdf) Averaging all the sites within a given region (open circles in Fig. 2), we determine a "regional mean" (solid gray triangles) annual cycle of MDA8 $\mathrm{O}_{3}$. We then calculate: (1) $r^{2}$ values between each site and the regional mean, as well as (2) the summation of the monthly mean deviations for each site from the regional mean. Each site is then assigned a ranking based on these two metrics. The rankings are then summed for each site (e.g., a ranking of "1" was assigned to the site with the highest correlation and also to the site with the lowest summed deviation for a cumulative ranking of "2"). The sites with the lowest summed ranking were classified as "regionally-representative" (stars in Fig. 1 and bold entries in Table A1). If the number of sites within a given region is $<5$, then 2 regionally-representative sites are chosen; if 5-12 sites are in a region, then 3 representative sites are chosen; if $>12$ sites are in a region, then 4 representative sites are chosen. For the California region, it is difficult to classify regionally-representative sites due to the widely varying topography, meteorology and influence of local emissions (California Air Resources Board, 2001); we selected Death Valley (DEV) and Yosemite (YOS) National Park sites 


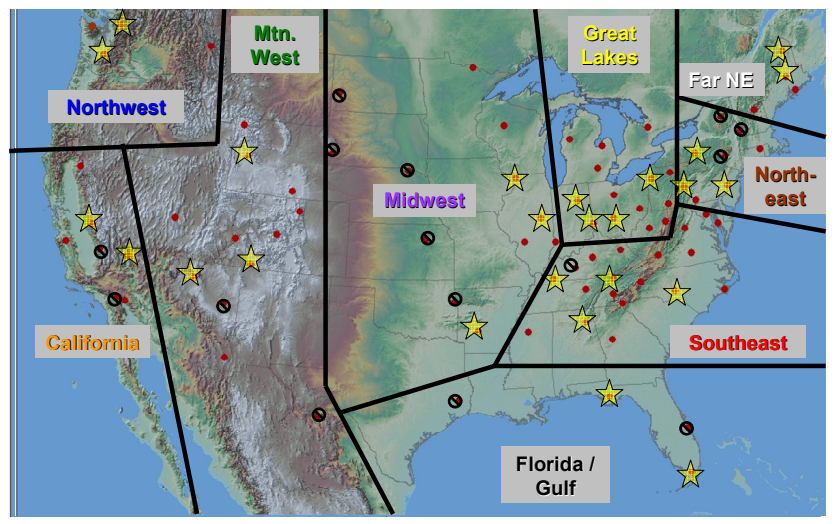

Fig. 1. Map of the 83 CASTNet sites (red dots) in the US. Geographic regions used in our analysis for the year 2001 are divided with black lines. "Regionally-representative" sites are highlighted with stars (criteria discussed in Sect. 2.1). Sites with more than 30 consecutive days of missing data for 2001 (and therefore excluded from our analysis) are denoted by black circles with lines through them.

because they represent site elevation extremes and had the best rankings.

We compare MDA8 $\mathrm{O}_{3}$ values for 2001 with the CASTNet climatology over the 1989-2004 period to examine whether 2001 was representative of typical conditions. Results for all years are illustrated in Fig. 3 for the Mountain West and Southeast regions (Fig. A2 shows the other 7 regions). From a policy-perspective, we are concerned with the number of exceedances days (when MDA8 $\mathrm{O}_{3}>75 \mathrm{ppbv}$ ). Table 1 shows the climatology (through 2004) of exceedance days for each site within a region. Exceedance days for the "Region" are determined by calculating the number of exceedances for each regionally representative site and then averaging these values for a given region. Using the current US EPA standard of the 4th highest MDA8 $\mathrm{O}_{3}>75 \mathrm{ppbv}$ to classify an exceedance of the air quality standard, Table 1 shows that sites in the California, Midwest, Great Lakes, Northeast and Southeast regions are regularly in exceedance.

To put the values from Fig. 3 (and Fig. A2) and Table 1 in context, we calculate seasonal mean $\mathrm{MDA} 8 \mathrm{O}_{3}$ values and compare them to the climatological values (through 2004) in Table 2. We define a $\pm 3 \%$ threshold deviation from the climatology to classify the season as "non-normal". Only one season in one region had a seasonal mean MDA8 $\mathrm{O}_{3}$ value that was $>1 \sigma$ (where $\sigma$ indicates standard deviation) from the climatological mean for that season (MAM in the Far Northeast). During summer (JJA), all regions had MDA8 $\mathrm{O}_{3}$ values that were at or below normal, with the Southeast ( -1.4 ppbv or $-3.7 \%)$, Florida/Gulf $(-2.2$ ppbv or $-7.2 \%)$ and Great Lakes $(-2.8$ ppbv or $-6.2 \%)$ regions exhibiting the greatest below-normal deviations. The East coast (with the exception of the Florida/Gulf region) experienced an above-normal $\mathrm{O}_{3}$ season in autumn ( $\mathrm{SON}$ ), while the northernmost regions (Northwest and Far Northeast regions)

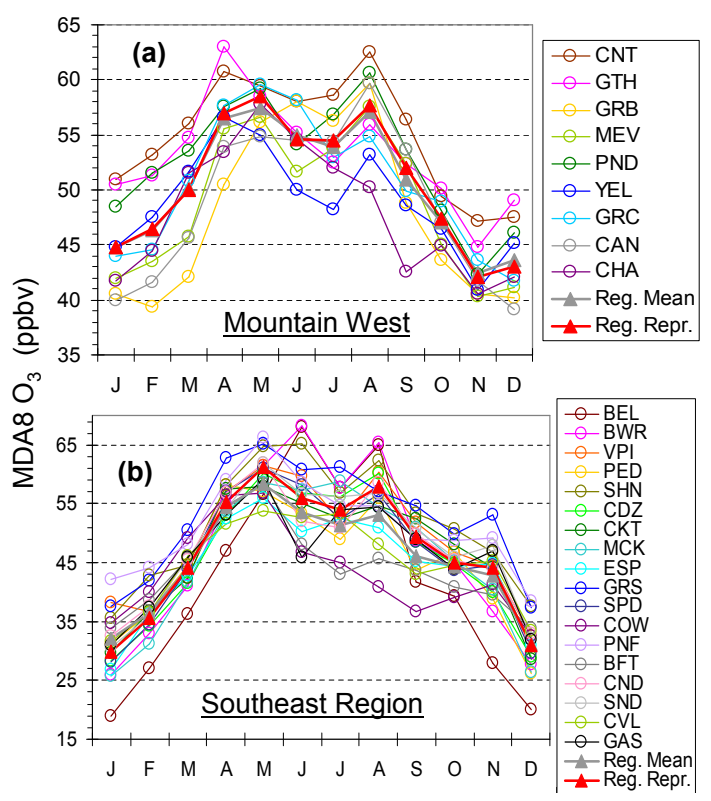

Fig. 2. Monthly mean MDA8 $\mathrm{O}_{3}$ at the individual CASTNet sites (open circles) and the multi-site regional mean (solid gray triangles) in the (a) Mountain West and (b) Southeast regions. Regionallyrepresentative sites for the Mountain West region are Mesa Verde NP, CO (MEV), Pinedale, WY (PND) and Grand Canyon NP, AZ (GRC); and Cadiz, KY (CDZ), Candor, NC (CND), Sand Mountain, AL (SND) and Speedwell, TN (SPD) for the Southeast region; the mean of these regionally-representative sites is depicted with solid red triangles. Geographic information and 3-letter abbreviations for all sites are listed in Table A1. Note the difference in the range of the $y$-axes between the two regions.

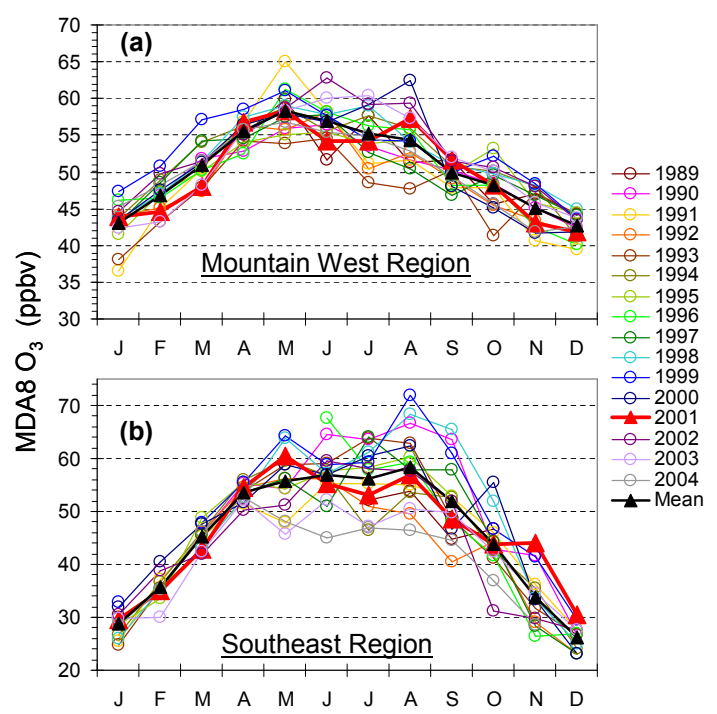

Fig. 3. Climatology of monthly mean $\mathrm{MDA} 8 \mathrm{O}_{3}$ for the mean of the regionally-representative sites in the (a) Mountain West and (b) Southeast regions. Solid red triangles indicate the HTAP year of 2001 (and represent the same data shown as solid red triangles as in Fig. 2); solid black triangles depict the multi-year average climatology. Datapoints are missing if $<21$ days of MDA $8 \mathrm{O}_{3}$ data exist for that month. Note the difference in the range of the y-axes between the two regions. 
also saw anomalously high $\mathrm{O}_{3}$ seasons in spring (MAM) at $+11.1 \%$ ( $+5.4 \mathrm{ppbv})$ and $+5.8 \%$ ( $+4.5 \mathrm{ppbv})$, respectively.

\subsection{Model simulations}

Sixteen CTMs (Table A2) provided hourly surface ozone for a "base-case" year 2001 simulation from which we calculated MDA8 $\mathrm{O}_{3}$ for our analysis. Tables 1 and $\mathrm{A} 1-\mathrm{A} 3$ in Fiore et al. (2009) describe meteorological fields and emissions inventories used by the 16 CTMs for the HTAP simulations. Methane concentrations were set to a uniform mixing ratio of $1760 \mathrm{ppb}$, while each modeling group was asked to employ their best estimate of $\mathrm{O}_{3}$-precursor emissions for 2001 and a minimum initialization time of six months to allow the simulated trace gas concentrations to fully respond to the imposed perturbation.

Relative to the base-case simulations, perturbation experiments were conducted by 12 of the modeling groups (denoted by \# in Table A2) in which anthropogenic $\mathrm{O}_{3}$-precursor emissions $\left(\mathrm{NO}_{\mathrm{x}}, \mathrm{NMVOC}, \mathrm{CO}\right.$ and aerosols) were reduced by $20 \%$ in each of the four source regions depicted in Fig. A3 (EA, SA, EU and NA). We estimate the MDA8 $\mathrm{O}_{3}$ response to simultaneous reductions in multiple source regions as the sum of the $\mathrm{O}_{3}$ responses to the individual regional reductions (e.g., $\mathrm{EA}+\mathrm{SA}+\mathrm{EU})$. The $20 \%$ emissions reduction represents a policy-relevant possibility, as well as a compromise between producing a detectable response in the $\mathrm{O}_{3}$ simulations and applying a sufficiently small perturbation to allow the results to be scaled linearly to perturbations of different magnitudes (Fiore et al., 2009). The applicability of scaling and linearity of an $\mathrm{O}_{3}$ response to changes in precursor emissions with respect to the HTAP experiments is discussed in further detail by Wu et al. (2009). In our analysis all models were sampled at the lowest model level in the grid cell containing the measurement site. We present uncertainty as $1 \sigma$ of the multi-model mean unless otherwise stated, where $\sigma$ is calculated from the simulated values at each site. The spread across models is just one metric for quantifying the uncertainty in a multi-model ensemble (Fiore et al., 2009). The model values are determined in a way directly analogous to the CASTNet observations: daily regional mean MDA8 $\mathrm{O}_{3}$ values represent the average of the values at each of the regionally representative sites.

\section{Model evaluation with CASTNet observations}

Utilizing observations alone to directly determine "sensitivities" (i.e., responses to emissions changes) is very difficult. Such efforts have been made at elevated free tropospheric sites like the Mt Bachelor Observatory (Weiss-Penzias et al., 2006) using the $\Delta \mathrm{Hg} / \Delta \mathrm{CO}$ enhancement ratio as a metric for quantifying the Asian contribution to air sampled in the US. However, similar studies at lower elevation sites (e.g., Goldstein et al., 2004; Fischer et al., 2009) concluded that it is very difficult to elucidate a foreign contribution signal unless there are events of very large magnitude. As a result, modeling experiments such as the HTAP simulations are essential to understand the more continuous, lower-signal foreign contribution to air quality in downwind regions. Future work is needed to design/determine observations that can be used to directly test the model capability to capture the ozone response to emissions perturbations (i.e., the sensitivity rather than simply total ozone)

Many of the models used here have been extensively evaluated against $\mathrm{O}_{3}$ observations in previous publications. We summarize the results from recent multi-model evaluation efforts in which many of the same models participated. Ellingsen et al. (2008) compared $\mathrm{O}_{3}$ concentrations from 18 models (10 of which are used in this study) to surface observations and found that levels and seasonality were reproduced well and that annual average biases were $\leq 5 \mathrm{ppbv}$ for regions in North America and Europe, but were larger (15-20 ppbv) in some regions where observations were more sparse. Stevenson et al. (2006) evaluated 26 models (10 of which are used in this study) with global ozonesonde measurements and found that the multi-model mean closely resembled the observations (within $1 \sigma$ of each other). They also showed that the multi-model mean tended to underestimate the amplitude of the seasonal cycle at $30-90^{\circ} \mathrm{N}$, overestimating winter $\mathrm{O}_{3}$ by $\sim 10 \mathrm{ppbv}$.

To our knowledge, this is the first evaluation of multiple global models with observed metrics relevant for air quality (i.e., MDA8 $\mathrm{O}_{3}$ ). It is essential to understand how well the models reproduce the observations before interpreting the perturbation simulation results. Figure 4 shows monthly mean MDA8 $\mathrm{O}_{3}$ from each of the $16 \mathrm{CTMs}$, the CASTNet observations, and the multi-model mean for the Mountain West and Southeast regions (Fig. A4 illustrates the model evaluation for the other seven regions). Recall, here (and onward) we present regional values as averages of the observations from regionally-representative sites and the models sampled at those sites. The multi-model mean represents the observations quite well in most regions during most seasons with a mean $r^{2}=0.57$ (average of all multi-model mean vs. observations correlations in Table 3 in all regions and seasons), although the individual models span a wide range (76$145 \%$ of observations during spring in the Mountain West and $77-151 \%$ of observations in the Southeast during autumn). The greatest model spread occurs during summer for most regions (modeled values are 45-227\% of observations depending on the region). In most cases, a given model performs similarly across all regions (i.e., if it overestimates observations in the Mountain West, it also overestimates observations in the Southeast and elsewhere). A review of CTM studies of tropospheric $\mathrm{O}_{3}$ found that cross-tropopause transport, deposition, humidity and lightning all contribute to inter-model differences (Wild, 2007). Near the surface, uncertainties in deposition, humidity and isoprene chemistry are probably driving the inter-model spread shown here. 
Table 1. Climatology of exceedance days for each region (defined as MDA8 $\mathrm{O}_{3}>75$ ppbv). Exceedance days for "Region" are determined by averaging the number of exceedance days from each regionally representative site in that region. Site-specific exceedance days occur when the daily MDA8 $\mathrm{O}_{3}>75$ ppbv for that site.

\begin{tabular}{|c|c|c|c|c|c|c|c|c|c|c|c|c|c|c|c|c|c|c|}
\hline & \multicolumn{3}{|c|}{ California } & \multicolumn{3}{|c|}{ Northwest } & \multicolumn{4}{|c|}{ Mtn. West } & \multicolumn{4}{|c|}{ Midwest } & \multicolumn{4}{|c|}{ Great Lakes } \\
\hline & DEV & YOS & Region & MOR & NCS & Region & PND & GRC & MEV & Region & BVL & CAD & STK & Region & $\mathrm{MKG}$ & DCP & OXF & SAL \\
\hline 1988 & - & - & - & - & - & - & - & - & - & - & - & - & - & - & 47 & 0 & 58 & 0 \\
\hline 1989 & - & - & - & - & - & - & 0 & 0 & 0 & 0 & 22 & 3 & 0 & 8.3 & 22 & 23 & 32 & 21 \\
\hline 1990 & - & - & - & - & - & - & 0 & 0 & 0 & 0 & 17 & 4 & 0 & 7 & 18 & 24 & 25 & 16 \\
\hline 1991 & - & - & - & - & - & - & 0 & 1 & 0 & 0.3 & 24 & 2 & 0 & 8.7 & 38 & 30 & 34 & 24 \\
\hline 1992 & - & - & - & - & - & - & 0 & 3 & 0 & 1 & 7 & 3 & 0 & 3.3 & 13 & 10 & 8 & 11 \\
\hline 1993 & - & - & - & - & - & - & 0 & 0 & 0 & 0 & 4 & 2 & 0 & 2 & 27 & 16 & 17 & 0 \\
\hline 1994 & - & - & - & - & - & - & 0 & 1 & 0 & 0.3 & 18 & 3 & 7 & 9.3 & 17 & 24 & 27 & 20 \\
\hline 1995 & - & - & - & 0 & 0 & 0 & 0 & 0 & 0 & 0 & 24 & 7 & 11 & 14 & 13 & 20 & 16 & 23 \\
\hline 1996 & 7 & 41 & 24 & 0 & 0 & 0 & 2 & 3 & 0 & 1.7 & 16 & 1 & 9 & 8.7 & 12 & 31 & 24 & 18 \\
\hline 1997 & 6 & 9 & 7.5 & 0 & 0 & 0 & 0 & 0 & 0 & 0 & 8 & 6 & 2 & 5.3 & 6 & 16 & 19 & 11 \\
\hline 1998 & 13 & 26 & 19.5 & 0 & 0 & 0 & 0 & 0 & 0 & 0 & 19 & 13 & 6 & 12.7 & 26 & 30 & 31 & 15 \\
\hline 1999 & 10 & 30 & 20 & 1 & 0 & 0.5 & 1 & 5 & 0 & 2 & 27 & 22 & 11 & 20 & 20 & 47 & 36 & 26 \\
\hline 2000 & 8 & 28 & 18 & 0 & 0 & 0 & 3 & 2 & 3 & 2.7 & 8 & 12 & 5 & 8.3 & 5 & 11 & 10 & 8 \\
\hline 2001 & 10 & 22 & 16 & 0 & 0 & 0 & 0 & 0 & 0 & 0 & 5 & 3 & 4 & 4 & 22 & 8 & 7 & 5 \\
\hline 2002 & 12 & 69 & 40.5 & 0 & 0 & 0 & 1 & 12 & 1 & 4.7 & 21 & 12 & 8 & 13.7 & 19 & 27 & 26 & 20 \\
\hline 2003 & 12 & 43 & 27.5 & 1 & 0 & 0.5 & 0 & 2 & 1 & 1 & 10 & 2 & 4 & 5.3 & 5 & 7 & 9 & 7 \\
\hline 2004 & 9 & 37 & 23 & 0 & 0 & 0 & 0 & 2 & 0 & 0.7 & 0 & 1 & 0 & 0.3 & 2 & 1 & 2 & 1 \\
\hline \multirow[t]{3}{*}{ Mean } & 9.7 & 33.9 & 21.8 & 0.2 & 0.0 & 0.1 & 0.4 & 1.9 & 0.3 & 0.9 & 14.4 & 6.0 & 4.2 & 8.2 & 18.4 & 19.1 & 22.4 & 13.3 \\
\hline & \multicolumn{3}{|c|}{ Far Northeast } & \multicolumn{4}{|c|}{ Northeast } & \multicolumn{5}{|c|}{ Southeast } & \multicolumn{3}{|c|}{ Florida/Gulf } & & & \\
\hline & HOW & $\mathrm{ASH}$ & Region & $\mathrm{CTH}$ & PSU & WSP & Region & SND & $\mathrm{CDZ}$ & SPD & CND & Region & EVE & SUM & Region & & & \\
\hline 1988 & - & - & - & 35 & 37 & 0 & 24 & - & - & - & - & - & - & - & - & & & \\
\hline 1989 & - & - & - & 10 & 8 & 33 & 17 & 14 & 0 & 1 & 0 & 3.8 & - & - & - & & & \\
\hline 1990 & - & - & - & 10 & 19 & 31 & 20 & 37 & 0 & 21 & 0 & 14.5 & - & - & - & & & \\
\hline 1991 & - & - & - & 30 & 39 & 49 & 39.33 & 6 & 0 & 6 & 2 & 3.5 & - & - & - & & & \\
\hline 1992 & - & - & - & 12 & 14 & 23 & 16.3 & 7 & 0 & 4 & 7 & 4.5 & - & - & - & & & \\
\hline 1993 & 2 & 0 & 1 & 12 & 29 & 35 & 25.3 & 16 & 0 & 2 & 17 & 8.8 & - & - & - & & & \\
\hline 1994 & 1 & 1 & 1 & 8 & 15 & 33 & 18.7 & 3 & 19 & 6 & 10 & 9.5 & - & - & - & & & \\
\hline 1995 & 2 & 0 & 1 & 11 & 17 & 42 & 23.3 & 16 & 19 & 16 & 11 & 15.5 & - & - & - & & & \\
\hline 1996 & 0 & 0 & 0 & 6 & 13 & 18 & 12.3 & 12 & 7 & 0 & 13 & 8 & - & - & - & & & \\
\hline 1997 & 2 & 1 & 1.5 & 10 & 14 & 14 & 12.7 & 8 & 10 & 11 & 26 & 13.8 & - & - & - & & & \\
\hline 1998 & 1 & 0 & 0.5 & 14 & 7 & 36 & 19 & 48 & 27 & 25 & 42 & 35.5 & 2 & 10 & 6 & & & \\
\hline 1999 & 2 & 1 & 1.5 & 12 & 26 & 34 & 24 & 52 & 33 & 23 & 32 & 35 & 3 & 4 & 3.5 & & & \\
\hline 2000 & 0 & 0 & 0 & 2 & 10 & 17 & 9.7 & 33 & 16 & 21 & 9 & 19.8 & 0 & 7 & 3.5 & & & \\
\hline 2001 & 2 & 0 & 1 & 10 & 17 & 26 & 17.7 & 9 & 4 & 9 & 9 & 7.8 & 0 & 2 & 1 & & & \\
\hline 2002 & 1 & 2 & 1.5 & 17 & 27 & 40 & 28 & 16 & 16 & 23 & 20 & 18.8 & 0 & 0 & 0 & & & \\
\hline 2003 & 1 & 0 & 0.5 & 7 & 4 & 9 & 6.7 & 7 & 2 & 1 & 3 & 3.3 & 1 & 4 & 2.5 & & & \\
\hline 2004 & 0 & 0 & 0 & 0 & 1 & 9 & 3.3 & 0 & 1 & 0 & 1 & 0.5 & 0 & 0 & 0 & & & \\
\hline Mean & 1.2 & 0.4 & 0.8 & 12.1 & 17.5 & 26.4 & 18.7 & 17.8 & 9.6 & 10.6 & 12.6 & 12.6 & 0.9 & 3.9 & 2.4 & & & \\
\hline
\end{tabular}

Table 3 summarizes the observations vs. multi-model mean MDA8 $\mathrm{O}_{3}$ statistics for spring, summer and autumn in each region. Seasonal statistics are calculated from the daily MDA8 $\mathrm{O}_{3}$ values; $n \approx 90$ for each season. Note, we have excluded winter (DJF) from our analysis for space considerations and because it is typically not a season of strong long-range transport from Asia to North America (compared to spring and autumn), surface $\mathrm{O}_{3}$ is at its annual minimum in almost every region of the US and exceedances of the national $\mathrm{O}_{3}$ standard are rare. Correlations between the models and observations averaged over the regionally-representative sites are generally stronger in the East $\left(r^{2}\right.$ ranges from $0.37-$ 0.80 ; mean $\left.r^{2}=0.61\right)$ than in the West $\left(r^{2}\right.$ ranges from $0.22-$ 0.81 ; mean $r^{2}=0.49$ ) and slightly more so in spring and fall $\left(r^{2}\right.$ ranges from 0.22-0.81; mean $\left.r^{2}=0.59\right)$ than in summer $\left(r^{2}\right.$ ranges from 0.32-0.73; mean $\left.r^{2}=0.53\right)$. In Fig. 5 we show daily MDA8 $\mathrm{O}_{3}$ from observations, the multi-model mean and $1 \sigma$ of the multi-model mean for spring, summer and autumn for the Mountain West and Southeast regions (the other 7 regions are shown in Fig. A5). In all regions, the spread of the models (indicated by the relative $\sigma$ of the multi-model mean, $\sigma_{r, m}$, defined as $\sigma_{\text {multi-modelmean }}$ divided by multi-model mean) peaks in summer $\left(\sigma_{r, m}\right.$ ranges from $0.20-0.25)$ and reaches a minimum in spring $\left(\sigma_{r, m}\right.$ ranges from 0.12-0.16). The multi-model mean correlates well with the observed values on synoptic time-scales, capturing large changes occurring over days to weeks. However, correlations are somewhat weaker in daily comparisons because the CTMs often fail to capture the magnitude of the day-to-day variability. 
Table 2. Seasonally-averaged $\mathrm{MDA} 8 \mathrm{O}_{3}$ deviations from the climatological mean for the HTAP year (2001) for each region. As we have defined it, a "high" ("low") MDA8 $\mathrm{O}_{3}$ season is one in which the seasonal deviation from the climatological average is greater than $+3 \%$ (more negative than $-3 \%$ ). A "normal" $\mathrm{MDA} 8 \mathrm{O}_{3}$ season, therefore, is one in which the seasonal mean did not deviate by more than $\pm 3 \%$ from climatology.

\begin{tabular}{|c|c|c|c|c|}
\hline \multirow[t]{2}{*}{ Region } & \multirow[t]{2}{*}{ Season } & \multicolumn{3}{|c|}{$\begin{array}{c}\text { Type of } \mathrm{O}_{3} \text { season in } 2001 \\
\text { (\% deviation from climatological mean) }\end{array}$} \\
\hline & & High & Normal & Low \\
\hline Northwest & $\begin{array}{r}\text { MAM } \\
\text { JJA } \\
\text { SON }\end{array}$ & $\begin{array}{r}+11.1 \\
+8.5\end{array}$ & -1.9 & \\
\hline California & $\begin{array}{r}\text { MAM } \\
\text { JJA } \\
\text { SON }\end{array}$ & & $\begin{array}{l}+1.5 \\
-0.7 \\
-0.7\end{array}$ & \\
\hline Mtn West & $\begin{array}{r}\text { MAM } \\
\text { JJA } \\
\text { SON }\end{array}$ & & $\begin{array}{l}-1.2 \\
-0.4 \\
-0.3\end{array}$ & \\
\hline Midwest & $\begin{array}{r}\text { MAM } \\
\text { JJA } \\
\text { SON }\end{array}$ & & $\begin{array}{l}+1.7 \\
+0.7 \\
-2.4\end{array}$ & \\
\hline Great Lakes & $\begin{array}{r}\text { MAM } \\
\text { JJA } \\
\text { SON }\end{array}$ & & $\begin{array}{l}-0.1 \\
+1.4\end{array}$ & -6.2 \\
\hline Far Northeast & $\begin{array}{r}\text { MAM } \\
\text { JJA } \\
\text { SON }\end{array}$ & $\begin{array}{l}+5.8 \\
+5.0\end{array}$ & -0.2 & \\
\hline Northeast & $\begin{array}{r}\text { MAM } \\
\text { JJA } \\
\text { SON }\end{array}$ & +8.2 & $\begin{array}{l}-1.2 \\
-0.6\end{array}$ & \\
\hline Southeast & $\begin{array}{r}\text { MAM } \\
\text { JJA } \\
\text { SON }\end{array}$ & +4.2 & +2.2 & -3.7 \\
\hline Florida/Gulf & $\begin{array}{r}\text { MAM } \\
\text { JJA } \\
\text { SON }\end{array}$ & & & $\begin{array}{l}-4.5 \\
-7.2 \\
-3.2\end{array}$ \\
\hline
\end{tabular}

While the multi-model mean captures the magnitude of MDA8 $\mathrm{O}_{3}$ and frequency of exceedance days in the western US quite well, large positive biases are found along the East coast and westward into the Midwest region from summer and into autumn. Table 3 illustrates these seasonal biases in the multi-model mean for each region, ranging from +5 to +20 ppbv. The largest positive biases in modeled MDA8 $\mathrm{O}_{3}$ occur in the Southeast and Great Lakes regions during summer. Interestingly, in the region of most complex terrain (Mountain West) where one could imagine the models having a difficult time accurately capturing the magnitude of $\mathrm{O}_{3}$ the multi-model mean actually exhibits the smallest bias (ranging from $+0.3 \mathrm{ppbv}$ in summer to $-3.0 \mathrm{ppbv}$ in spring). Liang and Jacobson (2000) show that integrated ozone production may be overpredicted by as much as $60 \%$ in coarse-

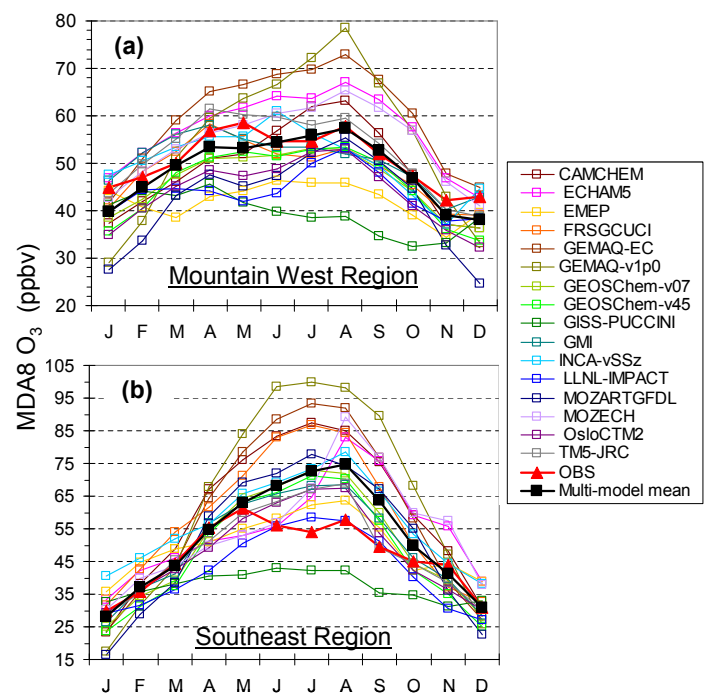

Fig. 4. Observed (solid red triangles; same as in Figs. 2 and 3) monthly mean MDA8 $\mathrm{O}_{3}$ for the (a) Mountain West Region and (b) Southeast Region, calculated by averaging the data from the regionally-representative sites shown in Fig. 1 (GRC, MEV and PND for the Mountain West region; CDZ, CND, SND and SPD for the Southeast region). Monthly mean $\mathrm{MDA} 8 \mathrm{O}_{3}$ values (sampled at the lowest layer) from each individual model (open squares) and the 16-model mean (solid black squares) were determined by averaging the results from the grid box where each regionally representative site is located. Note the large bias in the models during summer in the Southeast region and also the difference in $y$-axis ranges.
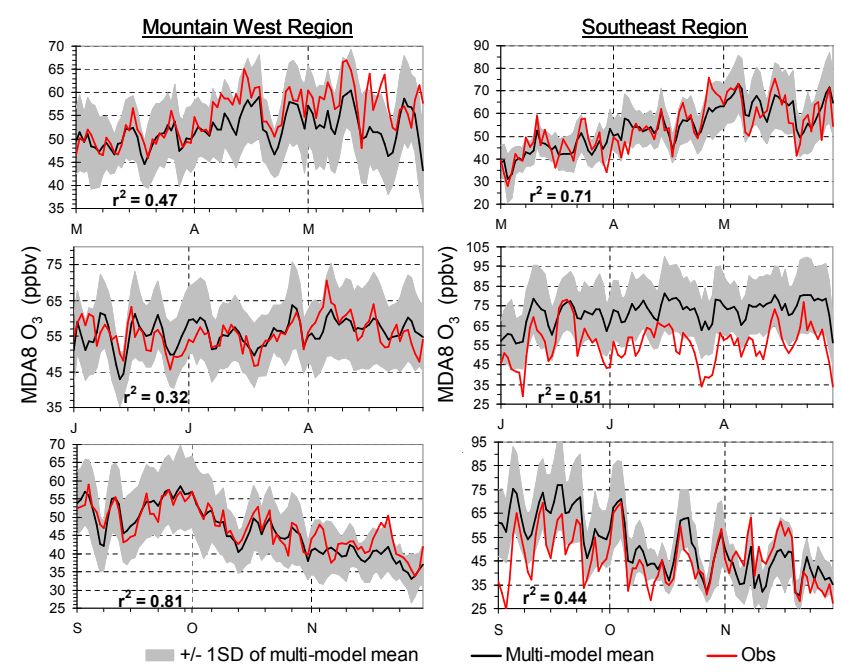

Fig. 5. Daily MDA8 $\mathrm{O}_{3}$ from observations (red line), multi-model mean (black line) and $1 \sigma$ of the multi-model mean (gray shading) for spring (MAM), summer (JJA) and autumn (SON) in the Mountain West region (left) and Southeast region (right) averaged over the regionally-representative sites depicted in Fig. 1. Note the range of magnitudes on the y-axes.

model grid cells as emissions of $\mathrm{O}_{3}$-precursors are artificially diluted, which could contribute to the multi-model overestimate in the eastern US. Murazaki and Hess (2006) also reveal a positive bias in MOZART simulations of $\mathrm{O}_{3}$ over the east- 
Table 3. Region-by-region statistics (mean $\pm 1 \sigma$ and $r^{2}$ ) for 2001 seasonally-averaged $\mathrm{MDA} 8 \mathrm{O}_{3}$ from observations vs. the multi-model mean. Exceedance days occur when MDA8 $\mathrm{O}_{3}>75 \mathrm{ppbv}$ and are calculated as described in Table 1 . Each mean, $\sigma$ and $r^{2}$ includes all daily MDA8 $\mathrm{O}_{3}$ values for that season; $n \approx 90$.

\begin{tabular}{|c|c|c|c|c|c|c|c|c|c|c|c|}
\hline \multirow[t]{3}{*}{ Region } & \multicolumn{6}{|c|}{ MDA8 $\mathrm{O}_{3}$, Mean $+1 \sigma(\mathrm{ppbv})$} & \multicolumn{3}{|c|}{$r^{2}$} & \multicolumn{2}{|c|}{ \# Exceedance Days } \\
\hline & \multicolumn{2}{|c|}{ MAM } & \multicolumn{2}{|c|}{ JJA } & \multicolumn{2}{|c|}{ SON } & \multirow[t]{2}{*}{ JJA } & \multirow[t]{2}{*}{ SON } & \multirow[t]{2}{*}{ Obs } & \multirow[b]{2}{*}{ Obs } & \multirow[b]{2}{*}{$\begin{array}{l}\text { Multi- } \\
\text { model } \\
\text { mean }\end{array}$} \\
\hline & Obs & $\begin{array}{l}\text { Multi- } \\
\text { model } \\
\text { mean }\end{array}$ & Obs & $\begin{array}{l}\text { Multi- } \\
\text { model } \\
\text { mean }\end{array}$ & Obs & $\begin{array}{l}\text { Multi- } \\
\text { model } \\
\text { mean }\end{array}$ & & & & & \\
\hline Northwest & $37 \pm 6$ & $43 \pm 4$ & $31 \pm 11$ & $38 \pm 8$ & $23 \pm 6$ & $35 \pm 5$ & 0.36 & 0.64 & 0.22 & 0 & 0 \\
\hline California & $54 \pm 7$ & $52 \pm 5$ & $66 \pm 8$ & $61 \pm 9$ & $53 \pm 10$ & $50 \pm 11$ & 0.46 & 0.43 & 0.74 & 16 & 3 \\
\hline Mtn West & $55 \pm 5$ & $52 \pm 4$ & $56 \pm 4$ & $56 \pm 4$ & $47 \pm 6$ & $46 \pm 7$ & 0.47 & 0.32 & 0.81 & 0 & 0 \\
\hline Midwest & $48 \pm 9$ & $47 \pm 7$ & $54 \pm 10$ & $65 \pm 8$ & $38 \pm 11$ & $43 \pm 12$ & 0.60 & 0.45 & 0.70 & 4 & 10 \\
\hline Great Lakes & $49 \pm 12$ & $49 \pm 11$ & $56 \pm 12$ & $72 \pm 10$ & $38 \pm 13$ & $44 \pm 16$ & 0.70 & 0.46 & 0.75 & 11 & 43 \\
\hline Far Northeast & $48 \pm 8$ & $44 \pm 6$ & $38 \pm 12$ & $48 \pm 12$ & $33 \pm 8$ & $38 \pm 11$ & 0.54 & 0.48 & 0.68 & 1 & 0 \\
\hline Northeast & $48 \pm 13$ & $48 \pm 11$ & $59 \pm 14$ & $71 \pm 11$ & $40 \pm 14$ & $43 \pm 16$ & 0.59 & 0.68 & 0.80 & 18 & 48 \\
\hline Southeast & $54 \pm 11$ & $54 \pm 9$ & $56 \pm 10$ & $72 \pm 6$ & $46 \pm 11$ & $52 \pm 12$ & 0.71 & 0.51 & 0.44 & 8 & 34 \\
\hline Florida/Gulf & $44 \pm 11$ & $55 \pm 7$ & $30 \pm 9$ & $50 \pm 8$ & $36 \pm 9$ & $51 \pm 7$ & 0.70 & 0.71 & 0.37 & 1 & 0 \\
\hline
\end{tabular}

ern US and hypothesize that this could be due, at least in part, to MOZART's exclusion of elevated point sources of emissions and incomplete heterogeneous chemistry scheme. The authors go on to note that the fundamental nonlinearity of the chemistry of $\mathrm{O}_{3}$ and the heterogeneity of surface emissions of $\mathrm{O}_{3}$-precursors further complicate matters in simulating $\mathrm{O}_{3}$ with global models. The issue of overestimating $\mathrm{O}_{3}$ is not limited to global models, however. Godowitch et al. (2008), Gilliland et al. (2008) and Nolte et al. (2008) find positive $\mathrm{O}_{3}$ biases in regional models over the eastern US, as well, which they largely attribute to uncertainties in temperature, relative humidity and planetary boundary layer height.

\section{Impact of foreign emissions on US surface $\mathrm{O}_{3}$}

Figure 6 shows the sum of the MDA8 $\mathrm{O}_{3}$ responses across the distribution of MDA8 $\mathrm{O}_{3}$ values to emissions reductions in the three foreign source regions $(\mathrm{EA}+\mathrm{SA}+\mathrm{EU}$, hereafter referred to as "foreign emissions"). The slight multi-model underestimate of MDA8 $\mathrm{O}_{3}$ during spring in the Mountain West and overestimate in the Southeast during summer are depicted as offsets between the red triangles (observations) and black squares (multi-model mean). In contrast, in the Mountain West during summer and in the Southeast during spring, the two lines nearly lie atop one another, indicating very good agreement in the number of days in each bin between the multi-model mean and the observations. A comparison between the Mountain West and Southeast regions illustrates broad characteristics that hold true for general East vs. West US regions (see Fig. A6 for the MDA8 $\mathrm{O}_{3}$ response in the seven other US regions), so we generalize results where applicable.

In summer, the multi-model mean over-predicts MDA8 $\mathrm{O}_{3}$ in many regions by a substantial amount (10-20 ppbv) and in

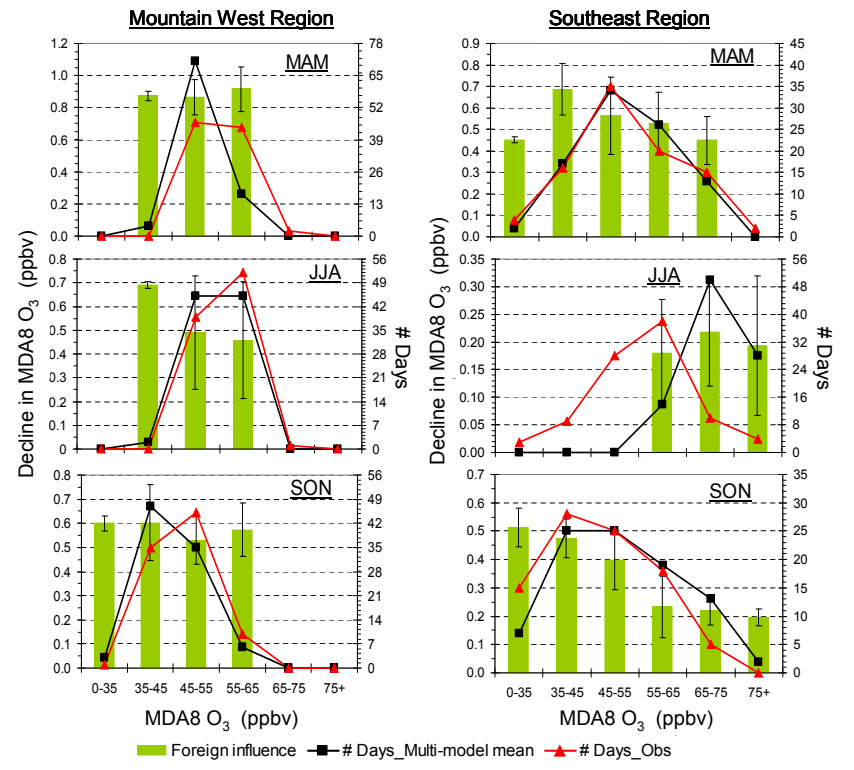

Fig. 6. Number of days for each MDA8 $\mathrm{O}_{3}$ bin (right-axis) from the multi-model mean (black squares) and observations (red triangles) and the sum of the responses of MDA8 $\mathrm{O}_{3}$ to $20 \%$ emissions reductions of anthropogenic $\mathrm{O}_{3}$-precursors $\left(\mathrm{NO}_{\mathrm{x}}+\mathrm{CO}+\mathrm{NMVOC}+\right.$ aerosols $)$ in the three foreign source regions (left-axis; green columns with error bars representing $1 \sigma$ of the multi-model mean) in the Mountain West (left) and Southeast (right) regions, binned by simulated $\mathrm{MDA} 8 \mathrm{O}_{3}$, for spring (MAM), summer (JJA) and autumn (SON). Note the range of magnitudes on the y-axes.

spring the multi-model mean under-predicts the values in the western US by a smaller amount ( $\sim 3 \mathrm{ppbv})$. We explored whether these biases were correlated with the model calculated contributions from NA or foreign sources (Fig. 7a and 

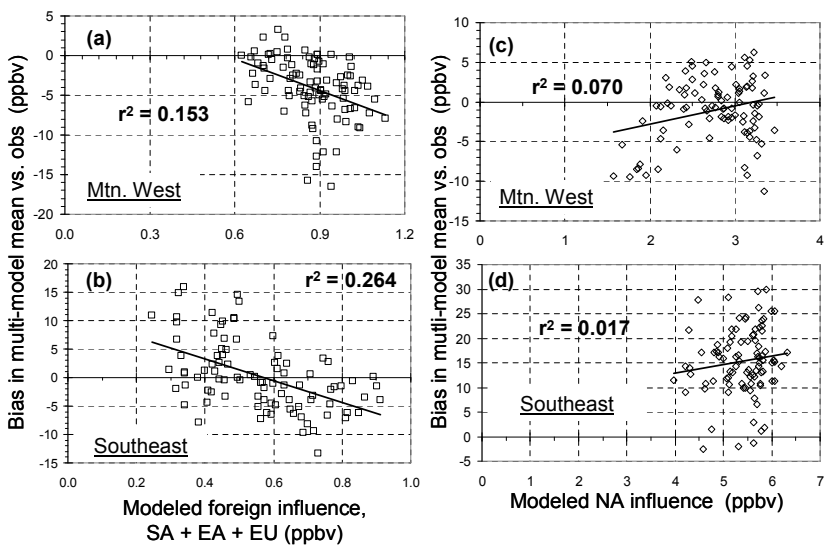

Fig. 7. Bias in the multi-model mean vs. the modeled influence from the three foreign source regions (SA + EA + EU; Fig. A3) during MAM in the (a) Mountain West and (b) Southeast regions. Similar plots but for the modeled NA influence during JJA are shown for the (c) Mountain West and (d) Southeast regions.

b). For spring, the negative bias shows a statistically significant relationship with the model calculated foreign contribution both in the western US and the Southeast region. This relationship holds true for most regions of the country (Fig. A7). For summer, the multi-model mean shows essentially no relationship between the positive bias and model calculated NA contribution. These results suggest that the multi-model mean may be under-predicting the foreign contribution, however other factors that vary in the same way could also explain this result. In contrast, the lack of a relationship between the summer bias and the domestic contribution (Fig. 7c and d) argues that the bias is present in nearly all airmasses (bias ranges from -2 to $+30 \mathrm{ppbv}$ ), regardless of the degree of local $\mathrm{O}_{3}$ buildup.

\subsection{Seasonal and regional differences in the influence from foreign emissions}

Figure 6 reveals the well-documented peak in foreign influence on surface $\mathrm{O}_{3}$ in the western US during spring (e.g., Holzer et al., 2005; Liang et al., 2004; Wang et al., 2006), and we show here that foreign influence on surface $\mathrm{O}_{3}$ in the eastern US also peaks in spring. Each individual model simulated this change in seasonal influences. In the western US, a $20 \%$ anthropogenic emissions reduction in the three $\mathrm{NH}$ foreign source regions decreases MDA8 $\mathrm{O}_{3}$ by $\sim 0.9 \mathrm{ppbv}$ in spring. In contrast, the response of MDA8 $\mathrm{O}_{3}$ in the eastern US to the same emissions reductions in spring is approximately $50 \%$ less at $\sim 0.55 \mathrm{ppbv}$. In the western US, the summed response to foreign emissions reductions of $20 \%$ is $\sim 0.5 \mathrm{ppbv}$ in summer and $\sim 0.6 \mathrm{ppbv}$ in autumn. Similar values for the eastern US are $\sim 0.2 \mathrm{ppbv}$ in summer and $\sim 0.4$ ppbv in autumn.
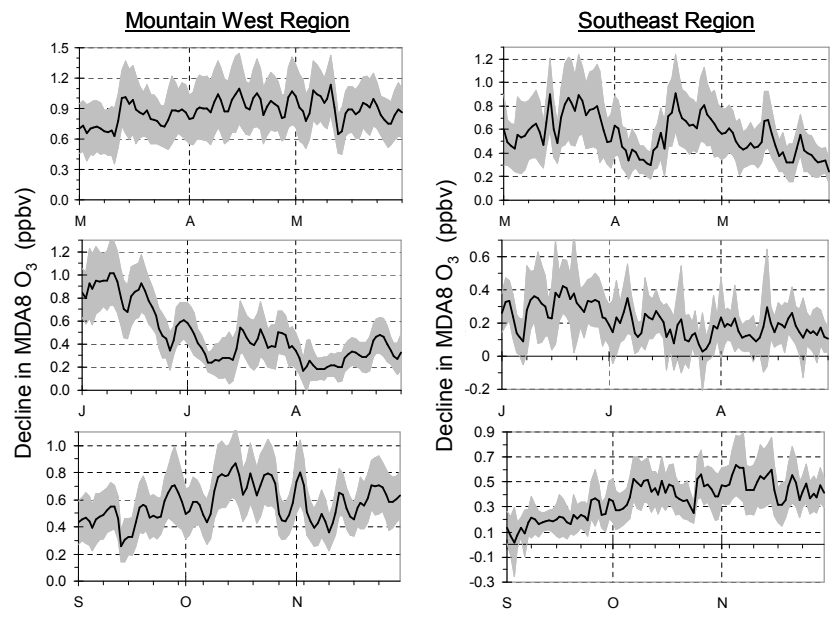

Fig. 8. Multi-model mean (black line) and $1 \sigma$ of the multi-model mean (gray shading) in the day-to-day variability of the sum of the responses of MDA8 $\mathrm{O}_{3}$ to $20 \%$ emissions reductions in anthropogenic $\mathrm{O}_{3}$-precursors $\left(\mathrm{NO}_{\mathrm{x}}+\mathrm{CO}+\mathrm{NMVOC}+\right.$ aerosols $)$ in the three foreign sources regions $(\mathrm{SA}+\mathrm{EA}+\mathrm{EU}$; Fig. A3) for the Mountain West (left) and Southeast regions (right). Note the range of magnitudes on the y-axes.

In Fig. 8 we show the multi-model mean (black line) $\pm 1 \sigma$ (gray shading) summed MDA8 $\mathrm{O}_{3}$ response to the foreign emissions reductions of $20 \%$ at daily resolution for the Mountain West and Southeast regions (Fig. A8 shows the results for the other seven regions). Note that in contrast to Fig. 5, there is no way to use observations to directly confirm the results presented in Fig. 8. The season of greatest intercontinental influence (spring) is also the season of greatest inter-model spread in the foreign influence, both in absolute $(\sigma)$ and relative $\left(\sigma_{r, m}\right)$ terms. An annual cycle in the magnitude of the foreign impact on MDA8 $\mathrm{O}_{3}$ can be seen in all regions, peaking in spring, declining by over $50 \%$ in summer and increasing slightly in autumn to return to values that are $\sim 33 \%$ below the maximum influence in spring. It is worth noting that no model predicts a foreign influence on the order of tens of ppbv of $\mathrm{O}_{3}$ that have been reported through observational studies (Yienger et al., 2000; Kotchenruther et al., 2001; Hudman et al., 2004; Jaffe et al., 2004; Weiss-Penzias et al., 2004; Keating et al., 2005). If we linearly scale even the strongest model surface $\mathrm{O}_{3}$ response to $100 \%$ emissions reduction in the three foreign source regions, the maximum event in the western US during spring has a summed foreign contribution of $\sim 9 \mathrm{ppbv}$ ( $\sim 2 \mathrm{ppbv}$ from SA; $\sim 4 \mathrm{ppbv}$ from EA; $\sim 3$ ppbv from EU). However, these observational studies are not directly comparable to the multi-model results presented here for several reasons: (1) most of these observational studies are free tropospheric/elevated aircraft studies, whereas we focus on surface $\mathrm{O}_{3}$, (2) the observational studies often focus on foreign influence within a plume, whereas the multi-model results have been averaged over a large spatial area, and (3) observational studies typically attribute 
total contribution from a given source region, whereas we are quantifying a $20 \%$ reduction in emissions from a given source region and any linear extrapolation introduces uncertainty (Wu et al., 2009).

\subsection{Influence of foreign emissions over the range of $\mathrm{MDAS} \mathrm{O}_{3}$ values}

From a policy-perspective, it is important to understand how intercontinental transport of pollution affects different parts of the $\mathrm{O}_{3}$ distribution. If foreign emissions have a greater impact at the high-end of the $\mathrm{O}_{3}$ distribution (i.e., are significantly contributing to exceedances in air quality standards), efforts at formulating international air pollution treaties should be a priority (Holloway et al., 2003). Figure 6 (and A6) show(s) that in the western US during spring, there is a nearly constant response across the $\mathrm{MDA} 8 \mathrm{O}_{3}$ distribution $(\sim 0.9$ ppbv reduction in response to a summed $20 \%$ emissions reduction). This result is simulated in each individual model. In contrast, during summer in the western US, there is a decreasing influence from intercontinental transport as MDA8 $\mathrm{O}_{3}$ values increase. This leads us to conclude that while intercontinental transport significantly affects high- $\mathrm{O}_{3}$ values during spring in the western US, it is less of a concern during summer, when most exceedances of air quality standards occur.

Shifting our attention to the eastern US regions in Figs. 6 and $\mathrm{A} 6$, the influence of foreign emissions of MDA8 $\mathrm{O}_{3}$ in spring (and autumn) is greatest $(\sim 0.7 \mathrm{ppbv}$ in response to a summed $20 \%$ emissions reduction in $\mathrm{EA}+\mathrm{SA}+\mathrm{EU}$ ) at low values of $\mathrm{MDA} 8 \mathrm{O}_{3}$ and steadily declines towards higher values. In contrast, the effect of foreign emissions reductions is fairly flat across the $\mathrm{O}_{3}$ distribution during the " $\mathrm{O}_{3}$ season" of summer. It is also worth noting that the effect of intercontinental transport is greater at higher latitudes (Northeast and Great Lakes regions) than in the Southeast. While the response in MDA8 $\mathrm{O}_{3}$ to foreign emissions reductions is relatively small on the East coast $(0.2-0.45 \mathrm{ppbv})$, the effect is still significant at high- $\mathrm{O}_{3}$ values. If $\mathrm{O}_{3}$-precursor emissions continue to grow abroad (particularly in the EA and SA regions), intercontinental transport will play an increasing role in air quality exceedances in the eastern US.

\subsection{Response of US MDA8 $\mathrm{O}_{3}$ to emissions in individual source regions}

Figure 9 illustrates the multi-model mean response of MDA8 $\mathrm{O}_{3}$ to $20 \%$ anthropogenic emissions reductions in the three foreign source regions for each of the nine US regions during spring across the MDA8 $\mathrm{O}_{3}$ distribution. In almost all regions (and seasons) the influence from EA is slightly greater than that from EU, both of which are far greater than that from SA. Each individual model simulated this result. The lone exception to this is in the Northeast region where the EU influence is slightly greater than that from EA, al-

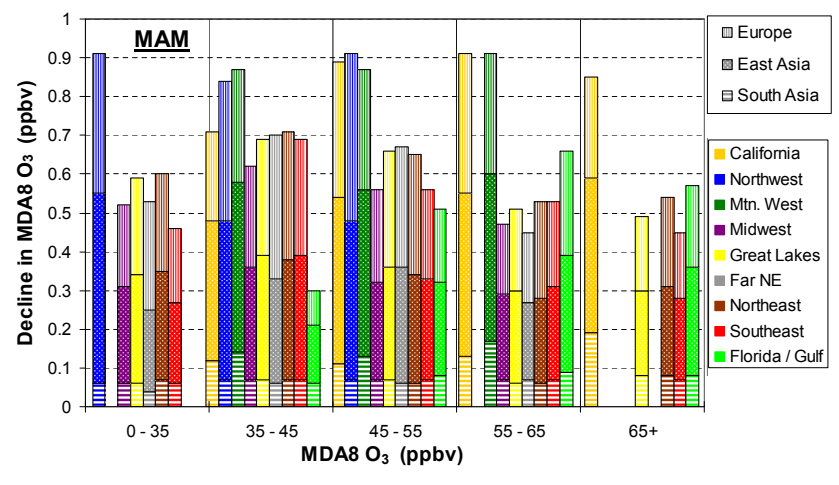

Fig. 9. The multi-model mean springtime (MAM) response of MDA8 $\mathrm{O}_{3}$ to $20 \%$ emissions reductions in anthropogenic $\mathrm{O}_{3}$ precursors $\left(\mathrm{NO}_{\mathrm{X}}+\mathrm{CO}+\mathrm{NMVOC}+\right.$ aerosols $)$ in the three foreign sources regions $(\mathrm{SA}+\mathrm{EA}+\mathrm{EU}$; Fig. A3), binned by simulated MDA8 $\mathrm{O}_{3}$, for each of the nine geographic regions illustrated in Fig. 1. For clarity, we have omitted error bars, but for each region in each bin, the cumulative $1 \sigma$ (i.e., sum of the $\sigma$ for each source region) of the multi-model mean is approximately \pm 0.15 ppbv. Missing bars indicate that no values from the multi-model mean fell within that bin.

though the difference is within the uncertainty as measured by the $\sigma$ in the individual model responses. The SA influence from a $20 \%$ reduction in anthropogenic $\mathrm{O}_{3}$-precursor emissions is $0.05-0.10 \mathrm{ppbv}$ with little variability across the range of MDA8 $\mathrm{O}_{3}$ values and in the various US regions. The EU influence peaks in the 35-65 ppbv range of the MDA8 $\mathrm{O}_{3}$ distribution, with typical decreases of $0.2-0.4 \mathrm{ppbv}$ from a $20 \%$ anthropogenic emissions reduction. The impact of $20 \%$ emissions reduction from EA on $\mathrm{MDA}_{8} \mathrm{O}_{3}$ is a $\sim 0.45 \mathrm{ppbv}$ reduction in the western U.S. (California, Northwest and Mountain West regions) that is fairly consistent across the $\mathrm{O}_{3}$ distribution. Elsewhere (i.e., east of the Rockies), the EA impact is $\sim 0.25 \mathrm{ppbv}$ with maximum EA influence in the $35-$ $55 \mathrm{ppbv}$ range of the $\mathrm{MDA} 8 \mathrm{O}_{3}$ distribution.

We can also use the results shown in Fig. 9 to compare the EA influence to trends in background $\mathrm{O}_{3}$ in the western US found in previous studies. As Fig. 9 shows, $0.4 \mathrm{ppbv}$ of the total 0.9 ppbv reduction in MDA8 $\mathrm{O}_{3}$ in the western US is due to the $20 \%$ emissions reductions in EA (model extremes show the EA contribution ranging from $0.20-0.64 \mathrm{ppbv}$ ). Assuming linearity, it follows that a $10 \% / y r$ increase in EA precursor emissions would correspond to an increase in MDA8 of $\sim 0.2 \mathrm{ppbv} / \mathrm{yr}$ (full range of models: $0.10-0.32 \mathrm{ppbv} / \mathrm{yr}$ ), which is similar in magnitude to the $0.34 \mathrm{ppbv} / \mathrm{yr}$ increase in mean daytime $\mathrm{O}_{3}$ reported by Jaffe and Ray (2007). While the magnitude - and even existence - of trends in background $\mathrm{O}_{3}$ in the western US remains debatable (e.g., Jaffe and Ray 2007; Oltmans et al., 2008; Parrish et al., 2008), the results presented herein will allow future investigations to compare possible trends to the well-documented $\mathrm{O}_{3}$-precursor emissions increases in East Asia (Irie et al., 2005; Richter et al., 2005). 


\section{North American emissions and US surface $\mathrm{O}_{3}$}

In Fig. 10 (Fig. A9) we present the $\mathrm{MDA} 8 \mathrm{O}_{3}$ response across the distribution of MDA8 $\mathrm{O}_{3}$ values to the $20 \%$ emissions reductions in the NA source region. As was the case for the foreign emissions reductions simulations, a comparison between the Mountain West and Southeast regions illustrates broad characteristics that hold true for general East vs. West US regions (see also Fig. A9) in the NA simulations, as well. In contrast to Fig. 7a and b (the foreign influence), Fig. 7c and d (Fig. A7) shows that there is little correlation between the simulated NA influence and the multi-model bias.

\subsection{Seasonal and regional differences in the influence from NA emissions}

In contrast to the foreign influence, Fig. 10 (Fig. A9) shows that the impact from NA emissions reductions peaks in summer. For all regions, the inter-seasonal difference (i.e., summer vs. spring/autumn) is $\sim 25 \%$ when the comparison is done between days with the same MDA8 $\mathrm{O}_{3}$, whereas for the foreign emission reductions the inter-seasonal difference (i.e., spring vs. summer/autumn) is far greater at 30 $60 \%$. If these comparisons are made for all days, then the inter-seasonal difference would be a factor of 2 or more. This is largely driven by prevailing meteorology that allows for foreign emissions to be transported most efficiently in spring. NA emissions reductions have a far greater impact on MDA8 $\mathrm{O}_{3}$ in the eastern than western US. The maximum MDA8 $\mathrm{O}_{3}$ response from the daily data (Fig. 11) for the Mountain West region is $2.6 \mathrm{ppbv}$ in spring, $3.4 \mathrm{ppbv}$ in summer and $3.0 \mathrm{ppbv}$ in autumn, whereas in the Southeast, these same values are 5.0,6.3 and 5.8 ppbv, respectively. The effect of NA emissions reductions is almost twice as great in the eastern US because the density of anthropogenic precursor emissions (per unit surface area) is much higher east of the Mississippi River, in addition to large altitude differences and the associated differences in transport and chemical processing.

Figure 11 (Fig. A10) illustrates the day-to-day variability in the impact these 20\% NA anthropogenic emissions reductions have on $\mathrm{MDA}_{8} \mathrm{O}_{3}$. As was the case in Fig. 8 for the foreign influence, the inter-model spread is greatest in the season of maximum influence (i.e., summer in this case), both in absolute $(\sigma)$ and relative $\left(\sigma_{r, m}\right)$ terms. Depending on the season and range of MDA8 $\mathrm{O}_{3}$ values in consideration, a $20 \%$ reduction in domestic anthropogenic $\mathrm{O}_{3}$-precursor emissions results in a 4-7\% (3-5\%) decrease in MDA8 $\mathrm{O}_{3}$ in the Southeast (Mountain West). Consistent with our findings, Gégo et al. (2007) show that in response to the $\mathrm{NO}_{\mathrm{x}}$ State Implementation Plan Call - implemented in the early 2000s to reduce anthropogenic $\mathrm{NO}_{\mathrm{x}}$ in the eastern US - $\mathrm{O}_{3}$ concentrations at CASTNet sites in the Southeast fell by $\sim 18 \%$ on average to a $\sim 60 \% \mathrm{NO}_{\mathrm{x}}$ emissions reduction from July 1997-July 2004. A direct comparison to our results is difficult since

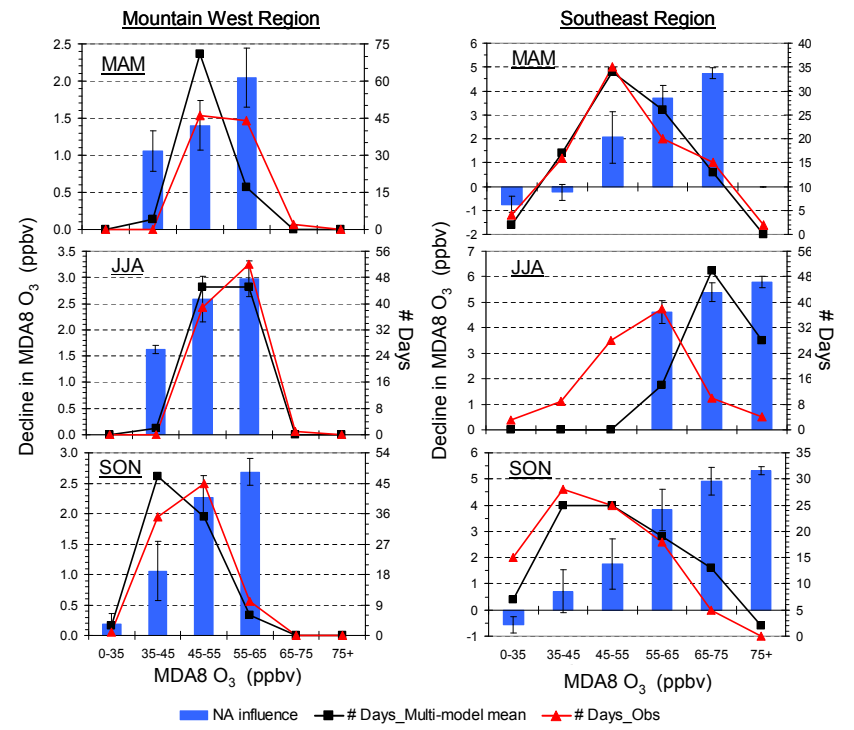

Fig. 10. As in Fig. 6, but for $20 \%$ emissions reductions of anthropogenic $\mathrm{O}_{3}$-precursors $\left(\mathrm{NO}_{\mathrm{x}}+\mathrm{CO}+\mathrm{NMVOC}+\right.$ aerosols $)$ in the North American source region (shown in Fig. A3). Note the range of magnitudes on the y-axes.
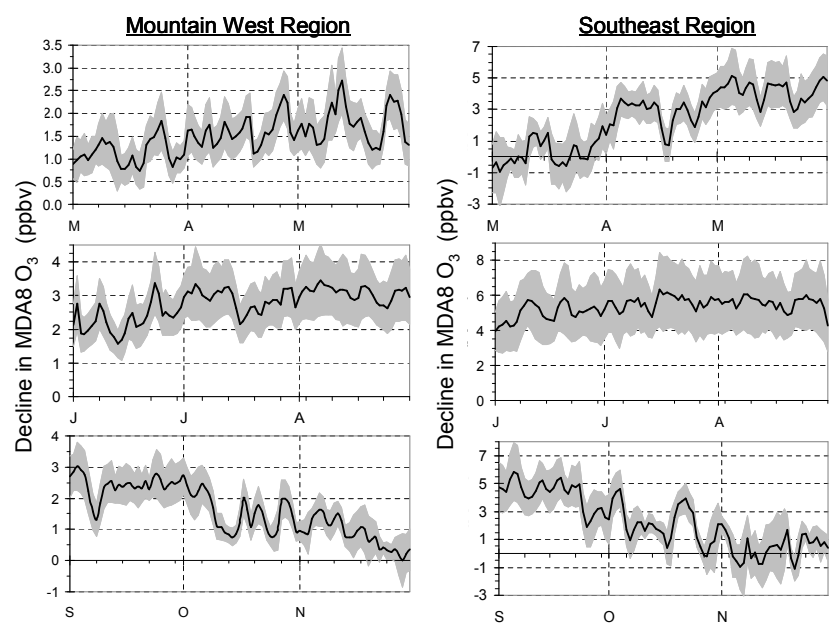

Fig. 11. As in Fig. 8, but for a $20 \%$ emissions reduction of anthropogenic $\mathrm{O}_{3}$-precursors $\left(\mathrm{NO}_{\mathrm{x}}+\mathrm{CO}+\mathrm{NMVOC}+\right.$ aerosols $)$ in the North American source region (shown in Fig. A3). Note the range of magnitudes on the y-axes.

the Gégo et al. (2007) study focuses on $\mathrm{NO}_{\mathrm{x}}$ emissions reductions alone (whereas the HTAP simulations also reduced $\mathrm{CO}$, VOCs and aerosols), but if we were to linearly scale their results, a $20 \% \mathrm{NO}_{\mathrm{x}}$ emissions reduction would cause a $\sim 6 \%$ decrease in MDA8 $\mathrm{O}_{3}$ in the Southeast, within the 4-7\% range we find through the HTAP experiments. Nevertheless, the large positive biases in the eastern US underscore the need for a better understanding and model parameterization of $\mathrm{O}_{3}$ chemistry and transport. 


\subsection{Influence of NA emissions over the range of MDA8 $\mathrm{O}_{3}$ values}

Figure 12 illustrates the binned summertime (JJA) response of MDA8 $\mathrm{O}_{3}$ to a $20 \%$ reduction in NA anthropogenic $\mathrm{O}_{3}$ precursor emissions for all regions. As MDA8 $\mathrm{O}_{3}$ increases, the impact NA emissions reductions have on $\mathrm{MDA} 8 \mathrm{O}_{3}$ increases in a fairly linear manner. Godowitch et al. (2008) reach a similar conclusion in finding that greater absolute decreases in MDA8 $\mathrm{O}_{3}$ occur at higher concentrations in response to $\mathrm{NO}_{\mathrm{x}}$ emissions reductions due to the $\mathrm{NO}_{\mathrm{x}}$ SIP Call. If we look at a region with data in the majority of MDA8 $\mathrm{O}_{3}$ bins (e.g., Northeast region), we find that the relative decrease in $\mathrm{MDA} 8 \mathrm{O}_{3}$ remains fairly constant at $\sim 6 \%$ in response to a $20 \%$ emissions reduction. The relative decrease is similarly constant across the $\mathrm{O}_{3}$ distribution for western regions, although the magnitude of the change is slightly lower at $\sim 4 \%$. In comparing the NA (Figs. 10 and A9) vs. foreign (Figs. 6 and A6) emissions reductions scenarios in their respective seasons of greatest influence, Fig. 10 (Fig. A9) shows that the MDA8 $\mathrm{O}_{3}$ response is $2-10$ times greater for NA emissions reductions in summer than for emissions reductions abroad in spring (Figs. 6 and A6). Coupling this with the fact that the NA emissions reductions have the greatest effect on MDA8 $\mathrm{O}_{3}$ when $\mathrm{O}_{3}$ air quality is typically of the greatest concern (i.e., summertime high- $\mathrm{O}_{3}$ events; Fiore et al., 2002, 2003) we conclude that NA emissions reductions remain a far more effective means of reducing the number of exceedance days, particularly in the eastern US.

\section{Summary and conclusions}

We present multi-model results from the HTAP experiments which reduced anthropogenic $\mathrm{O}_{3}$-precursor emissions by $20 \%$ in four northern hemispheric source regions. We quantify the influence of foreign and NA emissions reductions on surface MDA8 $\mathrm{O}_{3}$ throughout the US. We began by developing a novel method to determine "regionally-representative" sites to which the multi-model results were compared (Figs. 2 and A1). We provided context for the year of the HTAP simulations (2001) by comparing with 17 years of CASTNet data (Figs. 3 and A2). Through this analysis, we find that most regions of the US experienced "normal" (i.e., $\pm 3 \%$ of the 1988-2004 climatology) $\mathrm{O}_{3}$ seasons for 2001. Our evaluation of the CASTNet observations to the "base-case" results from the multi-model simulations (Figs. 4-5, and A4-A5; Table 3) revealed that individual models exhibit a very wide spread (e.g., max-min model differences of up to $\sim 60 \mathrm{ppbv}$ during summer in the Southeast), but that the multi-model mean represents the observations in most regions and seasons quite well (mean $r^{2}=0.57$ for all regions and in all seasons; mean annual biases typically $<5 \mathrm{ppbv}$ ). A notable exception to this is in the eastern US, where large positive biases exist, especially in summer (9-20 ppbv; 20-30\%).

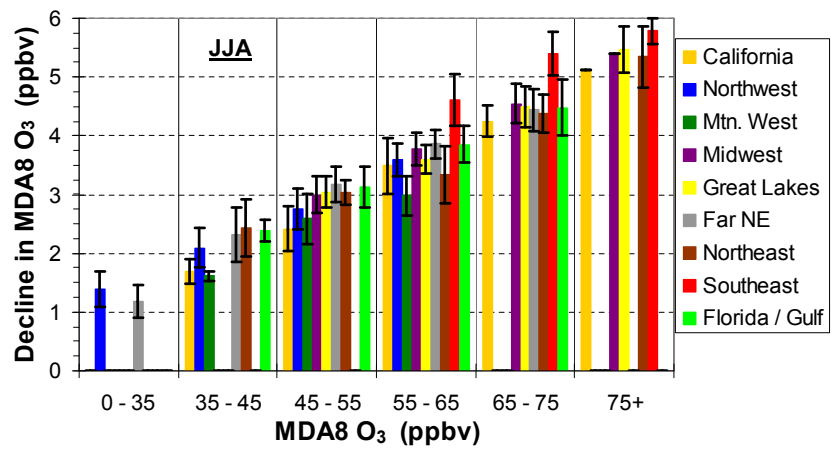

Fig. 12. The multi-model mean summertime (JJA) response of MDA8 $\mathrm{O}_{3}$ to a $20 \%$ reduction in anthropogenic $\mathrm{O}_{3}$-precursor emissions $\left(\mathrm{NO}_{\mathrm{x}}+\mathrm{CO}+\mathrm{NMVOC}+\right.$ aerosols $)$ in the North American source region (Fig. A3), binned by simulated $\mathrm{MDA} 8 \mathrm{O}_{3}$, for each of the nine geographic regions of the US. Error bars represent $1 \sigma$ of the multi-model mean response.

Results from the perturbation simulations in which foreign $(\mathrm{SA}+\mathrm{EA}+\mathrm{EU})$ anthropogenic $\mathrm{O}_{3}$-precursor emissions $\left(\mathrm{NO}_{\mathrm{x}}+\mathrm{NMVOC}+\mathrm{CO}+\right.$ aerosols $)$ were reduced by $20 \%$, show that the greatest impacts on $\mathrm{MDA}_{8} \mathrm{O}_{3}(\sim 0.9 \mathrm{ppbv})$ are in the western US during spring and that these responses are relatively flat across the $\mathrm{O}_{3}$ distribution (Figs. 6 and A6). In contrast, the eastern US shows a more muted MDA8 $\mathrm{O}_{3}$ response to anthropogenic emissions reductions abroad. The maximum response is still seen in spring (also with a summer minimum), but the magnitude of the responses decreases from $\sim 0.65 \mathrm{ppbv}$ at low MDA8 $\mathrm{O}_{3}$ values $(35-45 \mathrm{ppbv}$ ) to $\sim 0.30 \mathrm{ppbv}$ at high $\mathrm{O}_{3}$ values $(65+\mathrm{ppbv})$. For the foreign emissions considered (Fig. 9; SA vs. EA vs. EU), we find that EA emissions have the greatest effect on US air quality in almost all regions and seasons $(0.35-0.45 \mathrm{ppbv})$ followed closely by EU emissions (0.25-0.35 ppbv), both of which have a far greater impact than SA emissions (0.05$0.15 \mathrm{ppbv})$. The exception to this is in the Northeast, where the EU influence is slightly greater than that from EA. Simulations in which anthropogenic $\mathrm{O}_{3}$-precursor emissions were reduced by $20 \%$ in the NA source region (Figs. 10 and A9) resulted in a far greater impact on $\mathrm{O}_{3}$ air quality than foreign emissions reductions - by a factor of 2-10 - in the seasons of maximum influence (spring for foreign and summer for NA emissions reductions). Consistent with Fiore et al. (2002, 2003), the largest effects on MDA8 $\mathrm{O}_{3}$ (4-6 ppbv) are seen in the eastern US during summer at the high end of the $\mathrm{O}_{3}$ distribution $(65+\mathrm{ppbv})$. The western US also sees a maximum MDA8 $\mathrm{O}_{3}$ response in summer, but it is only $\sim 3-4$ ppbv.

These results should be interpreted in the context of the slight underestimation of MDA8 $\mathrm{O}_{3}$ by the multi-model mean in the western US during spring, which may cause the influence of foreign emissions on surface MDA8 $\mathrm{O}_{3}$ to be underestimated here (Figs. 7a, b and A7). Also, the large, positive biases in the multi-model mean in the eastern US 
during summer may cause the estimates of the NA emissions reductions in summer to be overestimated, though the lack of significant correlations in Fig. 7c and d (Fig. A7) precludes a definitive conclusion. It is difficult to quantify how these biases influence the estimated magnitudes of the surface $\mathrm{O}_{3}$ response to emission perturbations since the source(s) of these biases remains unknown. In light of this, our study still shows that while the impact of foreign emissions on surface ozone in the US is not negligible - and is of increasing concern given the recent growth in emissions in Asia - domestic emissions reductions remain a far more effective means of decreasing policy-relevant MDA8 $\mathrm{O}_{3}$ values (i.e., above the current air quality threshold of $75 \mathrm{ppbv}$ ), particularly in the $\mathrm{O}_{3}$ season.

Acknowledgements. This work has been funded in large part by NSF grant ATM-0724327. The authors wish to thank Jenise Swall and Steve Howard (EPA) for providing daily MDA8 $\mathrm{O}_{3}$ CASTNet data from 1988 through 2004 and Tracey Holloway (University of Wisconsin) for many fruitful discussions and comments. CA and DB were supported primarily by the US DOE Atmospheric Science Program (Office of Science, BER) at LLNL under Contract DE-AC52-07NA27344; BND from NASA MAP; AL from the Canadian Foundation for Climate and Atmospheric Sciences, the Ontario Ministry of the Environment, the Canadian Foundation for Innovation and the Ontario Innovation Trust; MGV from the Spanish Ministry of the Environment; and RJP was partly supported by the Korea Meteorological Administration Research and Development Program under Grant CATER 2007-3205.

Edited by: H. C. Hansson

\section{References}

Auvray, M., Bey, I., Llull, E., Schultz, M. G., and Rast, S.: A model investigation of tropospheric ozone chemical tendencies in long-range transported pollution plumes, J. Geophys. Res., 112, D05304, doi:10.1029/2006JD007137, 2007.

Bell, M. L., McDermott, A., Zeger, S. L., Samet, J. M., and Dominici, F.: Ozone and short-term mortality in 95 U.S. urban communities, 1987-2000, J. Amer. Med. Assoc., 292(19), 23722378, 2004.

Berntsen, T. K., Karlsdóttir, S., and Jaffe, D. A.: Influence of Asian emissions on the composition of air reaching the North Western United States, Geophys. Res. Lett., 26(14), 2171-2174, 1999.

Bertschi, I. T., Jaffe, D. A., Jaeglé, L., Price, H. U., and Dennison, J. B.: PHOBEA/ITCT 2002 airborne observations of transpacific transport of ozone, $\mathrm{CO}$, volatile organic compounds, and aerosols to the northeast Pacific: Impacts of Asian anthropogenic and Siberian boreal fire emissions, J. Geophys. Res., 109, D23S12, doi:10.1029/2003JD004328, 2004.

Casper-Anenberg, S., West, J. J., Fiore, A. M., Jaffe, D. A., Prather, M. J., Bergmann, D., Dentener, F. J., Duncan, B. N., Gauss, M., Hess, P., Jonson, J. E., Lupu, A., MacKenzie, I. A., Park, R. J., Sanderson, M., Schultz, M., Shindell, D. T., Szopa, S., Vivanco, M. G., Wild, O., and Zeng, G.: Impacts of intercontinen- tal source-receptor relationships for ozone pollution on human mortality, Environ. Sci. Technol., accepted, 2009.

Cooper, O. R., Stohl, A., Eckhardt, S., Parrish, D. D., Oltmans, S. J., Johnson, B. J., Nédlédec, P., Schmidlin, F. J., Newchurch, M. J., Kondo, Y., and Kita, K.: A springtime comparison of tropospheric ozone transport pathways on the east and west costs of the United States, J. Geophys. Res., 110, D05S90, doi:10.1029/2004JD005183, 2005.

Creilson, J. K., Fishman, J., and Wozniak, A. E.: Intercontinental transport of tropospheric ozone: a study of its seasonal variability across the North Atlantic utilizing tropospheric ozone residuals and its relationship to the North Atlantic Oscillation, Atmos. Chem. Phys., 3, 2053-2066, 2003,

http://www.atmos-chem-phys.net/3/2053/2003/.

Damoah, R., Spichtinger, N., Forster, C., James, P., Mattis, I., Wandinger, U., Beirle, S., Wagner, T., and Stohl, A.: Around the world in 17 days - hemispheric-scale transport of forest fire smoke from Russia in May 2003, Atmos. Chem. Phys., 4, 13111321, 2004, http://www.atmos-chem-phys.net/4/1311/2004/.

Eder, B. K., Sickles II, J. E., and Shadwick, D. S.: A Principal Component Analysis of the Clean Air Status and Trends Network (CASTNet) Air Concentration Data, US Environmental Protection Agency, Research Triangle Park, NC 27711, personal communication, 2005.

Ellingsen, K., Gauss, M., Van Dingenen, R., Dentener, F. J., Emberson, L., Fiore, A. M., Schultz, M. G., Stevenson, D. S., Ashmore, M. R., Atherton, C. S., Bergmann, D. J., Bey, I., Butler, T., Drevet, J., Eskes, H., Hauglustaine, D. A., Isaksen, I. S. A., Horowitz, L. W., Krol, M., Lamarque, J. F., Lawrence, M. G., van Noije, T., Pyle, J., Rast, S., Rodriguez, J., Savage, N., Strahan, S., Sudo, K., Szopa, S., and Wild, O.: Global ozone and air quality: a multi-model assessment of risks to human health and crops, Atmos. Chem. Phys. Discuss., 8, 2163-2223, 2008, http://www.atmos-chem-phys-discuss.net/8/2163/2008/.

Fiore, A. M., Jacob, D. J., Bey, I., Yantosca, R. M., Field, B. D., and Fusco, A. C.: Background ozone over the United States in summer: Origin, trend, and contribution to pollution episodes, J. Geophys. Res., 107(D15), doi:10.1029/2001JD000982, 2002.

Fiore, A., Jacob, D. J., Liu, H., Yantosca, R. M., Fairlie, T. D., and $\mathrm{Li}, \mathrm{Q}$.: Variability in surface ozone background over the United States: Implications for air quality policy, J. Geophys. Res., 108(D24), 4787, doi:10.1029/2003JD003855, 2003.

Fiore, A. M., Dentener, F. J., Wild, O., Cuvelier, C., Schultz, M. G., Hess, P., Textor, C., Schulz, M., Doherty, R. M., Horowitz, L. W., MacKenzie, I. A., Sanderson, M. G., Shindell, D. T., Stevenson, D. S., Szopa, S., Van Dingenen, R., Zeng, G., Atherton, C., Bergmann, D., Bey, I., Carmichael, G., Collins, W. J., Duncan, B. N., Faluvegi, G., Folberth, G., Gauss, M., Gong, S., Hauglustaine, D., Holloway, T., Isaksen, I. S. A., Jacob, D. J., Jonson, J. E., Kaminski, J. W., Keating, T. J., Lupu, A., Marmer, E., Montanaro, V., Park, R. J., Pitari, G., Pringle, K. J., Pyle, J. A., Schroeder, S., Vivanco, M. G., Wind, P., Wojcik, G., Wu, S., and Zuber, A.: Multimodel estimates of intercontinental sourcereceptor relationships for ozone pollution, J. Geophys. Res., 114, D04301, doi:10.1029/2008JD010816, 2009.

Fischer, E. V., Hsu, N. C., Jaffe, D. A., Jeong, M.-J., and Gong, S. L.: A decade of dust: Asian dust and springtime aerosol load in the U.S. Pacific Northwest, Geophys. Res. Lett., 36, L03821, 
doi:10.1029/2008GL036467, 2009.

Fuentes, M.: Statistical assessment of geographic areas of compliance with air quality standards, J. Geophys. Res., 108(D24), 9002, doi:10.1029/2003JD003672, 2003.

Gégo, E., Porter, P. S., Gilliland, A., and Rao, S. T.: Observationbased assessment of the impact of nitrogen oxides emissions reductions on ozone air quality over the eastern United States, J. Appl. Meteorol. Clim., 46, 994-1008, 2007.

Gilliland, A. B., Hogrefe, C., Pinder, R. W., Godowitch, J. M., Foley, K. L., and Rao, S. T.: Dynamic evaluation of regional air quality models: Assessing changes in $\mathrm{O}_{3}$ stemming from changes in emissions and meteorology, Atmos. Environ., 42, 5110-5123, 2008.

Godowitch, J. M., Gilliland, A. B., Draxler, R. R., and Rao, S. T.: Modeling assessment of point source $\mathrm{NO}_{\mathrm{x}}$ emission reductions on ozone air quality in the eastern United States, Atmos. Environ., 42, 87-100, 2008.

Goldstein, A. H., Millet, D. B., McKay, M., Jaeglé, L., Horowitz, L., Cooper, O., Hudman, R., Jacob, D. J., Oltmans, S., and Clarke, A.: Impact of Asian emissions on observations at Trinidad Head, California during ITCT 2K2, J. Geophys. Res., 109, D23S17, doi:10.1029/2003JD004406, 2004.

Heald, C. L., Jacob, D. J., Fiore, A. M., Emmons, L. K., Gille, J. C., Deeter, M. N., Warner, J., Edwards, D. P., Crawford, J. H., Hamlin, A. J., Sachse, G. W., Browell, E. V., Avery, M. A., Vay, S. A., Westberg, D. J., Blake, D. R., Singh, H. B., Sandholm, S. T., Talbot, R. W., and Fuelberg, H. E.: Asian outflow and transPacific transport of carbon monoxide and ozone pollution: An integrated satellite, aircraft, and model perspective, J. Geophys. Res., 108(D24), 4804, doi:10.1029/2003JD003507, 2003.

Hoell, J. M., Davis, D. D., Liu, S. C., Newell, R. E., Akimoto, H., McNeal, R. J., and Bendura, R. J.: The Pacific Exploratory Mission-West Phase B: February-March 1994, J. Geophys. Res., 102, 28,223-28,239, 1997.

Holland, D. M., Principe, P. P., and Vorburger, L.: Rural ozone: Trends and exceedances at CASTNet sites, Environ. Sci. Technol., 33, 43-48, 1999.

Holloway, T., Fiore, A., and Hastings, M. G.: Intercontinental transport of air pollution: Will emerging science lead to a new hemispheric treaty?, Environ. Sci. Technol., 37, 4535-4542, 2003.

Holzer, M., Hall, T. M., and Stull, R. B.: Seasonality and weatherdriven variability of transpacific transport, J. Geophys. Res., 110, D23103, doi:10.1029/2005JD0006261, 2005.

Hudman, R., Jacob, D. J., Cooper, O. R., Evans, M. J., Heald, C. L., Park, R. J., Fehsenfeld, F., Flocke, F., Holloway, J., Hübler, G., Kita, K., Koike, M., Kondo, Y., Neuman, A., Nowak, J., Oltmans, S., Parrish, D., Roberts, J. M., and Ryerson, T.: Ozone production in transpacific Asian pollution plumes and implications for ozone air quality in California, J. Geophys. Res., 109, D23S10, doi:10.1029/2004JD004974, 2004.

Hudman, R. C., Jacob, D. J., Turquety, S., Leibensperger, E. M., Murray, L. T., Wu, S., Gilliland, A. B., Avery, M., Bertram, T. H., Brune, W., Cohen, R. C., Dibb, J. E., Flocke, F. M., Fried, A., Holloway, J., Neuman, J. A., Orville, R., Perring, A., Ren, X., Sachse, G. W., Singh, H. B., Swanson, A., and Wooldridge, P. J.: Surface and lightning sources of nitrogen oxides over the United States: Magnitudes, chemical evolution and outflow, J. Geophys. Res., 112, D12S05, doi:10.1029/2006JD007912, 2007.

Irie, H., Sudo, K., Akimoto, H., Richter, A., Burrows, J. P., Wag- ner, T., Wenig, M., Beirle, S., Kondo, Y., Sinyakov, V. P., and Goutai, F.: Evaluation of long-term tropospheric $\mathrm{NO}_{2}$ data obtained by GOME over East Asia in 1996-2002, Geophys. Res. Lett., 32(11), L11810, doi:10.1029/2005GL022770, 2005.

Jacob, D. J., Logan, J. A., and Murti, P. P.: Effect of rising Asian emissions on surface ozone in the United States, Geophys. Res. Lett., 26(14), 2175-2178, 1999.

Jacob, D. J., Crawford, J. H., Kelb, M. M., Connors, V. S., Bendura, R. J., Raper, J. L., Sachse, G. W., Gille, J. C., Emmons, L., and Heald, C. L.: Transport and Chemical Evolution over the Pacific (TRACE-P) aircraft mission: Design, execution and first results, J. Geophys. Res., 108(D20), 9000, doi:10.1029/2002JD003276, 2003.

Jaffe, D., Anderson, T., Covert, D., Kotchenruther, R., Trost, B., Danielson, J., Simpson, W., Berntsen, T., Karlsdottir, S., Blake, D., Harris, J., Carmichael, G., and Uno, I.: Transport of Asian air pollution to North America, Geophys. Res. Lett., 26, 6, 711-714, 1999.

Jaffe, D., Anderson, T., Covert, D., Trost, B., Danielson, J., Simpson, W., Blake, D., Harris, J., and Streets, D.: Observations of ozone and related species in the northeast Pacific during the spring of 2001: Results from the PHOBEA II experiment, J. Geophys. Res., 108(D20), 8802, doi:10.1029/2002JD003121, 2001.

Jaffe, D., Bertschi, I., Jaeglé, L., Novelli, P., Reid, J. S., Tanimoto, H., Vingarzan, R., and Westphal, D. L.: Long-range transport of Siberian biomass burning emissions and impact on surface ozone in western North America, Geophys. Res. Lett., 31, L16106, doi:10.1029/2004GL020093, 2004.

Jaffe, D. and Ray, J.: Increase in surface ozone at rural sites in the western U.S., Atmos. Environ., 41, 5452-5463, 2007.

Jonson, J. E., Stohl, A., Fiore, A. M., Hess, P., Schulz, M., Wild, O., Zeng, G., Dentener, F. J., Lupu, A., Wind, P., Cuvelier, C., Keating, T. J., and Zuber, A.: A multi-model analysis of vertical profiles, Atmos. Chem. Phys. Discuss., in preparation, 2009.

Keating, T., West, J., and Jaffe, D.: Air quality impacts of intercontinental transport, EM The Magazine for Environmental Managers, AWMA, 28-30, October 2005.

Klonecki, A. and Levy, H.: Tropospheric chemical ozone tendencies in $\mathrm{CO}-\mathrm{CH}_{4}-\mathrm{NO}_{\mathrm{y}}-\mathrm{H}_{2} \mathrm{O}$ system: Their sensitivity to variations in environmental parameters and their application to a global chemistry transport model study, J. Geophys. Res., 102, 21 221-21 237, 1997.

Kotchenruther, R. A., Jaffe, D. A., and Jaeglé, L.: Ozone photochemistry and the role of peroxyacetyl nitrate in the springtime northeastern Pacific troposphere: Results from the Photochemical Ozone Budget of the Eastern North Pacific Atmosphere (PHOBEA) campaign, J. Geophys. Res., 106, 28 731-28 742, 2001.

Lefohn, A., Oltmans, S., Dann, T., and Singh, H.: Present-day variability of background ozone in the lower troposphere, J. Geophys. Res., 106(D9), 9945-9958, 2001.

Lehman, J., Swinton, K., Bortnick, S., Hamilton, C., Baldridge, E., Eder, B., and Cox, B.: Spatio-temporal characterization of tropospheric ozone across the eastern United States, Atmos. Environ., 38, 4357-4369, 2004.

Li, Q., Jacob, D. J., Bey, I., Palmer, P. I., Duncan, B. N., Field, B. D., Martin, R. V., Fiore, A. M., Yantosca, R. M., Parrish, D. D., Simmonds, P. G., and Oltmans, S. J.: Transatlantic transport of pollu- 
tion and its effects on surface ozone in Europe and North America, J. Geophys. Res., 107(D13), 4166, 10.1029/2001JD001422, 2002.

Li, Q., Jacob, D., Munger, J., Yantosca, R., and Parrish, D.: Export of $\mathrm{NO}_{\mathrm{y}}$ from the North American boundary layer: Reconciling aircraft observations and global model budgets, J. Geophys. Res., 109, D02313, doi:10.1029/2003JD004086, 2004.

Liang, J. Y. and Jacobson, M. Z.: Effects of subgrid segregation on ozone production efficiency in a chemical model, Atmos. Environ., 34, 2975-2982, 2000.

Liang, Q., Jaeglé, L., Jaffe, D. A., Weiss-Penzias, P., Heckman, A., and Snow, J. A.: Long-range transport of Asian pollution to the northeast Pacific: Seasonal variations and transport pathways of carbon monoxide, J. Geophys. Res., 109, D23S07, doi:10.1029/2003JD004402, 2004.

Liang, Q., Jaeglé, L., and Wallace, J. M.: Meteorological indices for Asian outflow and transpacific transport on daily to interannual timescales, J. Geophys. Res., 110, D18308, doi:10.1029/2005JD005788, 2005.

Liang, Q., Jaeglé, L., Hudman, R. C., Turquety, S., Jacob, D. J., Avery, M. A., Browell, E. V., Sachse, G. W., Blake, D. R., Brune, W., Ren, X., Cohen, R. C., Dibb, J. E., Fried, A., Fuelberg, H., Porter, M., Heikes, B. G., Huey, G., Singh, H. B., and Wennberg, P. O.: Summertime influence of Asian pollution in the free troposphere over North America, J. Geophys. Res., 112, D12S11, doi:10.1029/2006JD007919, 2007.

Lin, J.-T., Wuebbles, D. J., and Liang, X.-Z.: Effects of intercontinental transport on surface ozone over the United States: Present and future assessment with a global model, Geophys. Res. Lett., 35, L02805, doi:10.1029/2007GL031415, 2008.

Liu, H., Jacob, D. J., Bey, I., Yantosca, R. M., Duncan, B. N., and Sachse, G. W.: Transport pathways for Asian pollution outflow over the Pacific: Interannual and season variations, J. Geophys. Res., 108(D20), 8786, doi:10.1029/2002JD003102, 2003.

Liu, J., Mauzerall, D. L., and Horowitz, L. W.: Analysis of seasonal and interannual variability in transpacific transport, J. Geophys. Res., 110, D04302, doi:10.1029/2004JD005207, 2005.

Murazaki, K. and Hess, P.: How does climate change contribute to surface ozone change over the United States?, J. Geophys. Res., 111, D05301, doi:10.1029/2005JD005873, 2006.

Nolte, C. G., Gilliland, A. B., Hogrefe, C., and Mickley, L. J.: Linking global to regional models to assess future climate impacts on surface ozone levels in the United States, J. Geophys. Res., 113, D14307, doi:10.1029/2007JD008497, 2008.

Oltmans, S. J., Lefohn, A. S., Harris, J. M., and Shadwick, D. S.: Background ozone levels of air entering the west coast of the US and assessment of longer-term changes, Atmos. Environ., 42, 6020-6038, 2008.

Parrish, D. D., Kondo, Y., Cooper, O. R., Brock, C. A., Jaffe, D. A., Trainer, M., Ogawa, T., Hübler, G., and Fehsenfeld, F. C.: Intercontinental Transport and Chemical Transformation 2001 (ITCT 2K2) and Pacific Exploration of Asian Continental Emission (PEACE) experiments: An overview of the 2002 winter and spring intensives, J. Geophys. Res., 109, D23S01, doi:10.1029/2004JD004980, 2004a.

Parrish, D. D., Ryerson, T. B., Holloway, J. S., Neuman, J. A., Roberts, J. M., Williams, J., Stroud, C. A., Frost, G. J., Trainer, M., Hübler, G., Fehsenfeld, F. C., Flocke, F., and Weinheimer, A. $\mathrm{J}$. : Fraction and composition of $\mathrm{NO}_{\mathrm{y}}$ transported in air masses lofted from the North American continental boundary layer, J. Geophys. Res., 109, D09302, doi:10.1029/2003JD004226, 2004b.

Parrish, D. D., Millet, D. B., and Goldstein, A. H.: Increasing ozone in marine boundary layer inflow at the west coasts of North America and Europe, Atmos. Chem. Phys., 9, 1303-1323, 2009, http://www.atmos-chem-phys.net/9/1303/2009/.

Reidmiller, D. R., Jaffe, D. A., Chand, D., Strode, S., Swartzendruber, P., Wolfe, G. M., and Thornton, J. A.: Interannual variability of long-range transport as seen at the Mt. Bachelor observatory, Atmos. Chem. Phys., 9, 557-572, 2009, http://www.atmos-chem-phys.net/9/557/2009/.

Richter, A., Burrows, J. P., Nüß, H., Granier, C., and Niemeier, U.: Increase in tropospheric nitrogen dioxide over China observed from space, Nature, 437, 129-132, 2005.

Sanderson, M. G., Dentener, F. J., Fiore, A. M., Cuvelier, C., Keating, T. J., Zuber, A., Atherton, C. S., Bergmann, D. J., Diehl, T., Doherty, R. M., Duncan, B. N., Hess, P., Horowitz, L. W., Jacob, D. J., Jonson, J.-E., Kaminski, J. W., Lupu, A., MacKenzie, I. A., Mancini, E., Marmer, E., Park, R., Pitari, G., Prather, M. J., Pringle, K. J., Schroeder, S., Schultz, M. G., Shindell, D. T., Szopa, S., Wild, O., and Wind, P.: A multi-model study of the hemispheric transport and deposition of oxidized nitrogen, Geophys. Res. Lett., 35, L17815, doi:10.1029/2008GL035389, 2008.

Shindell, D. T., Chin, M., Dentener, F., Doherty, R. M., Faluvegi, G., Fiore, A. M., Hess, P., Koch, D. M., MacKenzie, I. A., Sanderson, M. G., Schultz, M. G., Schulz, M., Stevenson, D. S., Teich, H., Textor, C., Wild, O., Bergmann, D. J., Bey, I., Bian, H., Cuvelier, C., Duncan, B. N., Folberth, G., Horowitz, L. W., Jonson, J., Kaminski, J. W., Marmer, E., Park, R., Pringle, K. J., Schroeder, S., Szopa, S., Takemura, T., Zeng, G., Keating, T. J., and Zuber, A.: A multi-model assessment of pollution transport to the Arctic, Atmos. Chem. Phys., 8, 5353-5372, 2008, http://www.atmos-chem-phys.net/8/5353/2008/.

Singh, H. B., Brune, W. H., Crawford, J. H., Flocke, F., and Jacob, D. J.: Chemistry and transport of pollution over the Gulf of Mexico and the Pacific: spring 2006 INTEX-B campaign overview and first results, Atmos. Chem. Phys., 9, 2301-2318, 2009, http://www.atmos-chem-phys.net/9/2301/2009/.

Stevenson, D. S., Dentener, F. J., Schultz, M. G., Ellingsen, K., van Noije, T. P. C., Wild, O., Zeng, G., Amann, M., Atherton, C. S., Bell, N., Bergmann, D. J., Bey, I., Butler, T., Cofala, J., Collins, W. J., Derwent, R. G., Doherty, R. M., Drevet, J., Eskes, H. J., Fiore, A. M., Gauss, M., Hauglustaine, D. A., Horowitz, L. W., Isaksen, I. S. A., Krol, M. C., Lamarque, J.-F., Lawrence, M. G., Montanaro, V., Müller, J.-F., Pitari, G., Prather, M. J., Pyle, J. A., Rast, S., Rodriguez, J. M., Sanderson, M. G., Savage, N. H., Shindell, D. T., Strahan, S. E., Sudo, K., and Szopa, S.: Multimodel ensemble simulations of present-day and near-future tropospheric ozone, J. Geophys. Res., 111, D08301, doi:10.1029/2005JD006338, 2006.

Sudo, K. and Akimoto, H.: Global source attribution of tropospheric ozone: Long-range transport from various source regions, J. Geophys. Res., 112, D12302, doi:10/1029/2006JD007992, 2007.

Swartzendruber, P. C., Jaffe, D. A., Prestbo, E. M., Weiss-Penzias, P., Selin, N. E., Park, R., Jacob, D. J., Strode, S., and Jaeglé, L.: Observations of reactive gaseous mercury in the free tro- 
posphere at the Mount Bachelor Observatory, J. Geophys. Res., 111, D24301, doi:10.1029/2006JD007415, 2006.

TF HTAP - Task Force on Hemispheric Transport of Air Pollution: Hemispheric Transport of Air Pollution 2007 Interim Report, Air Pollution Studies No. 16, edited by: Keating, T. J. and Zuber, A., United Nations Economic Commission for Europe, New York, available at: www.htap.org, 2007.

Tong, D. Q. and Mauzerall, D. L.: Spatial variability of summertime tropospheric ozone over the continental United States: implications of an evaluation of the CMAQ model, Atmos. Environ., 40, 3041-3056, 2006.

US Environmental Protection Agency: Clean Air Status and Trends Network (CASTNet), Washington, DC, Annual Report-2006, 73 pp., available at: http://www.epa.gov/castnet/docs.html, 2007.

US Environmental Protection Agency: Clean Air Status and Trends Network (CASTNet) Fact Sheet, available at: www.epa.gov/ castnet/library/facts, 2008.

Wang, Y., Choi, Y., Zeng, T., Ridley, B., Blake, N., Blake, D., and Flocke, F.: Late-spring increase of trans-Pacific pollution transport in the upper troposphere, Geophys. Res. Lett., 33, L01811, doi:10.1029/2005GL024975, 2006.

Weiss-Penzias, P., Jaffe, D. A., Jaeglé, L., and Liang Q.,: Influence of long-range-transported pollution on the annual and diurnal cycles of carbon monoxide and ozone at Cheeka Peak Observatory, J. Geophys. Res., 109, D23S14, doi:10/1029/2004JD004505, 2004.

Weiss-Penzias, P., Jaffe, D. A., Swartzendruber, P., Dennison, J. B., Chand, D., Hafner, W., and Prestbo, E.: Observations of Asian air pollution in the free troposphere at Mount Bachelor Observatory during the spring of 2004, J. Geophys. Res., 111, D10304, doi:10.1029/2005JD006522, 2006.
Wenig, M., Spichtinger, N., Stohl, A., Held, G., Beirle, S., Wagner, T., Jähne, B., and Platt, U.: Intercontinental transport of nitrogen oxide pollution plumes, Atmos. Chem. Phys., 3, 387-393, 2003, http://www.atmos-chem-phys.net/3/387/2003/.

Wild, O.: Modelling the global tropospheric ozone budget: exploring the variability in current models, Atmos. Chem. Phys., 7, 2643-2660, 2007, http://www.atmos-chem-phys.net/7/2643/2007/.

Wu, S., Duncan, B. N., Jacob, D. J., Fiore, A. M., and Wild, O.: Chemical nonlinearities in relating intercontinental ozone pollution to anthropogenic emissions, Geophys. Res. Lett., 36, L05806, doi:10.1029/2008GL036607, 2009.

Yienger, J., Klonecki, A., Levy II, H., Moxim, W., and Carmichael, G.: An evaluation of chemistry's role in the winter-spring ozone maximum found in the northern midlatitude free troposphere, J. Geophys. Res., 104(D3), 3655-3667, 1999.

Yienger, J., Galanter, M., Holloway, T., Phandis, M., Guttikunda, S., Carmichael, G., Moxim, W., and Levy II, H.: The episodic nature of air pollution transport from Asia to North America, J. Geophys. Res., 105(D22), 26 931-26945, 2000.

Zhang, L., Jacob, D. J., Boersma, K. F., Jaffe, D. A., Olson, J. R., Bowman, K. W., Worden, J. R., Thompson, A. M., Avery, M. A., Cohen, R. C., Dibb, J. E., Flock, F. M., Fuelberg, H. E., Huey, L. G., McMillan, W. W., Singh, H. B., and Weinheimer, A. J.: Transpacific transport of ozone pollution and the effect of recent Asian emission increases on air quality in North America: an integrated analysis using satellite, aircraft, ozonesonde, and surface observations, Atmos. Chem. Phys., 8, 6117-6136, 2008, http://www.atmos-chem-phys.net/8/6117/2008/. 